
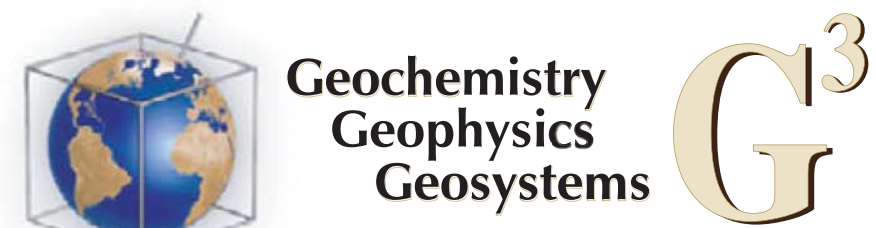

\title{
Nonvolcanic tectonic islands in ancient and modern oceans
}

\section{Camilla Palmiotto}

Dipartimento di Scienze Biologiche, Geologiche e Ambientali, Università di Bologna, Piazza di Porta San Donato 1, 40126 Bologna, Italy (camilla.palmiotto@bo.ismar.cnr.it)

Istituto di Scienze Marine, CNR, Bologna, Italy

\section{Laura Corda}

Dipartimento di Scienze della Terra, Università “La Sapienza”, Rome, Italy

\section{Marco Ligi}

Istituto di Scienze Marine, CNR, Bologna, Italy

\section{Anna Cipriani}

Lamont Doherty Earth Observatory, Columbia University, Palisades, New York, USA

Dipartimento di Scienze Chimiche e Geologiche, Università di Modena e Reggio Emilia, Modena, Italy

\section{Henry J. B. Dick}

Woods Hole Oceanographic Institution, Woods Hole, Massachusetts, USA

\section{Eric Douville}

Laboratoire des Sciences du Climat et de l'Environnement, Laboratoire mixte CNRS-CEA, Gif-sur-Yvette, France

\section{Luca Gasperini}

Istituto di Scienze Marine, CNR, Bologna, Italy

\section{Paolo Montagna}

Istituto di Scienze Marine, CNR, Bologna, Italy

Lamont Doherty Earth Observatory, Columbia University, Palisades, New York, USA

Laboratoire des Sciences du Climat et de l'Environnement, Laboratoire mixte CNRS-CEA, Gif-sur-Yvette, France

\section{François Thil}

Laboratoire des Sciences du Climat et de l'Environnement, Laboratoire mixte CNRS-CEA, Gif-sur-Yvette, France

\section{Anna Maria Borsetti}

Istituto di Scienze Marine, CNR, Bologna, Italy

\section{Barbara Balestra}

Institute of Marine Sciences, University of California Santa Cruz, Santa Cruz, California, USA 


\section{Enrico Bonatti}

Istituto di Scienze Marine, CNR, Bologna, Italy

\section{Lamont Doherty Earth Observatory, Columbia University, Palisades, New York, USA}

[1] Most oceanic islands are due to excess volcanism caused by thermal and/or compositional mantle melting anomalies. We call attention here to another class of oceanic islands, due not to volcanism but to vertical motions of blocks of oceanic lithosphere related to transform tectonics. Sunken tectonic islands capped by carbonate platforms have been previously identified along the Vema and Romanche transforms in the equatorial Atlantic. We reprocessed seismic reflection lines, did new facies analyses and ${ }^{87} \mathrm{Sr} /{ }^{86} \mathrm{Sr}$ dating of carbonate samples from the carbonate platforms. A $50 \mathrm{~km}$ long narrow paleoisland flanking the Vema transform, underwent subsidence, erosion, and truncation at sea level; it was then capped by a 500 $\mathrm{m}$ thick carbonate platform dated by ${ }^{87} \mathrm{Sr} /{ }^{86} \mathrm{Sr}$ at $\sim 11-10 \mathrm{Ma}$. Three former islands on the crest of the Romanche transverse ridge are now at $\sim 900 \mathrm{~m}$ bsl; they show horizontal truncated surfaces of oceanic crust capped by $\sim 300 \mathrm{~m}$ thick carbonate platforms, with 10-6 Ma Sr isotopic ages. These sunken islands formed due to vertical tectonics related to transtension/transpression along long-offset slow-slip transforms. Another tectonic sunken island is Atlantis Bank, an uplifted gabbroic block along the Atlantis II transform (SW Indian Ridge) 700 m bsl. A modern tectonic island is St. Peter and St. Paul Rocks, a rising slab of upper mantle located at the St. Paul transform (equatorial Atlantic). "Cold" tectonic islands contrast with "hot" volcanic islands related to mantle thermal and/or compositional anomalies along accretionary boundaries and within oceanic plates, or to supra-subduction mantle melting that gives rise to islands arcs.

Components : 11,624 words, 8 figures, 2 tables.

Keywords: tectonic islands; oceanic transform faults; carbonate platforms; facies analysis; strontium isotope stratigraphy; calcareous nannofossil biostratigraphy

Index Terms : 0930 Oceanic structures: Exploration Geophysics.

Received 10 June 2013; Revised 4 September 2013; Accepted 24 September 2013; Published 24 October 2013.

Palmiotto, C., et al. (2013), Nonvolcanic tectonic islands in ancient and modern oceans, Geochem. Geophys. Geosyst., 14, 4698-4717, doi:10.1002/ggge.20279.

\section{Introduction}

[2] Oceanic islands, such as those scattered across the Pacific ocean, can be viewed as anomalies relative to the "depth versus square root of age" law [Sclater et al., 1971], derived from cooling of oceanic plates as they move away from mid-ocean ridges. Since Wilson [1963] and Morgan [1972], oceanic islands have generally been regarded as due to excess volcanism, related to mantle thermal and/or compositional anomalies. In the Pacific they are generally aligned parallel to the motion of the Pacific plate (a classic example is the Hawaiian-Emperor Chain), probably because they form as the plate transits above a quasi-stationary plume. As a volcanic island leaves the plume site, volcanism ceases, the plate cools, and the island subsides and sinks below sea level, in a mechanism hinted at already by Darwin [1844].

[3] We describe here a different type of oceanic islands, i.e., nonvolcanic, tectonic islands formed by vertical motions of slivers of oceanic lithosphere due to transform tectonics. We will discuss old and new data on sunken tectonic islands capped by carbonate platforms detected close to equatorial Atlantic transform faults (Figure 1a) [Bonatti et al., 1977, 1983, 1994a, 1994b]. We reconstructed their origin, evolution and demise based on reprocessed seismic reflection profiles, and on new facies analysis as well as paleontological and $\mathrm{Sr}$ isotopic dating of carbonate samples. We will also describe an island formed by uplift and subsidence of a gabbroic block along the Atlantis II transform in the SW Indian Ridge 

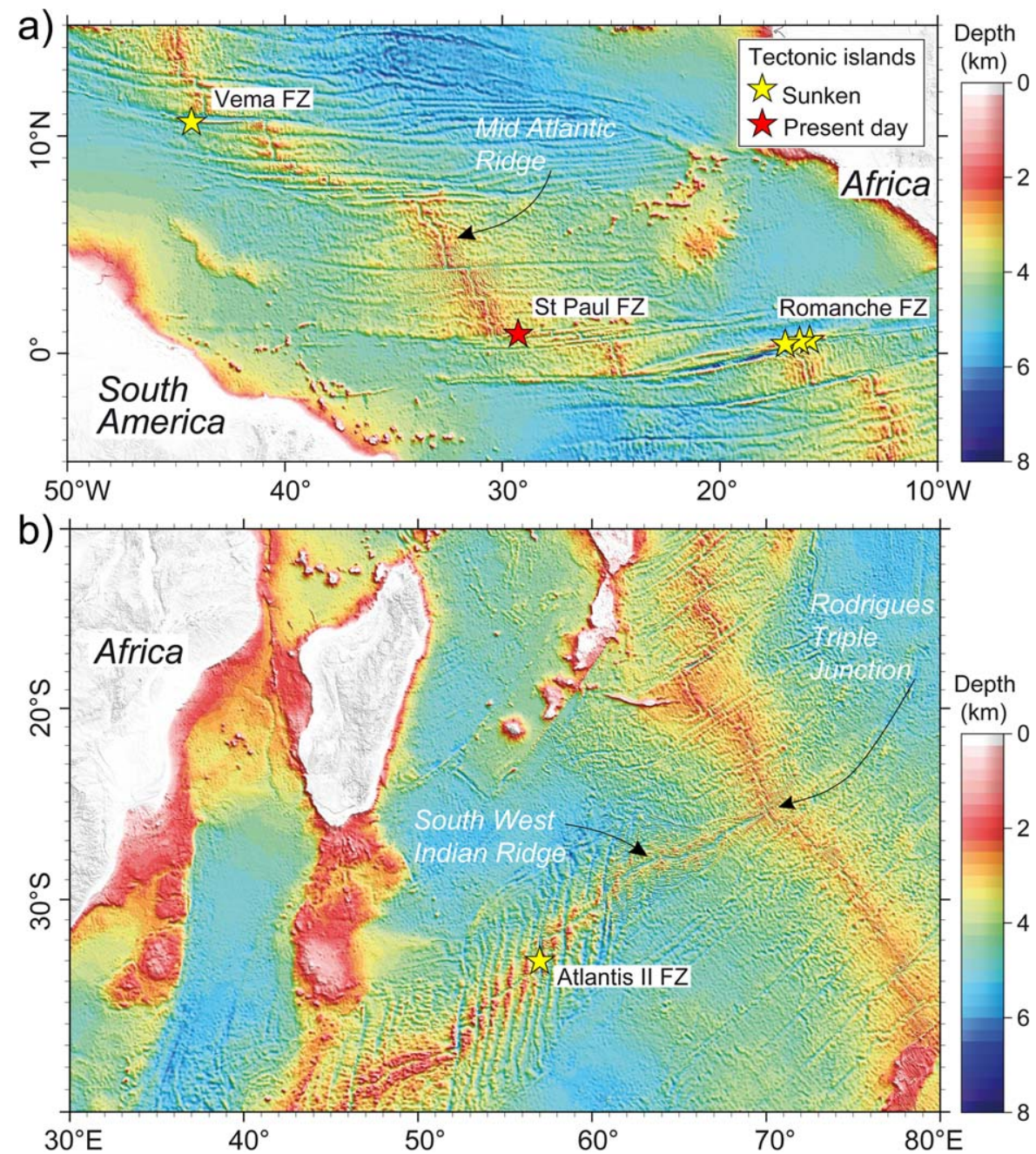

Figure 1. (a) Geographical and geological setting of the Vema, St. Paul, and Romanche fracture zones (FZs) along the equatorial Mid-Atlantic Ridge; (b) geographical and geological setting of the Atlantis II transform along the South West Indian Ridge. Bathymetry data are from General Bathymetric Chart of the Oceans (GEBCO_08 grid). Stars indicate locations of tectonic islands (yellow, sunken; red, modern).

(Figure 1b), and a present-day tectonic island, i.e., St. Peter-Paul Rocks in the equatorial Atlantic (Figure 1a). These observations on present-day and fossil tectonic islands will lead to a simple classification of oceanic islands based on their origin.

\section{Methods}

\subsection{Geophysics}

[4] Bathymetric and seismic reflection data summarized in this paper were obtained from the Vema and Romanche fracture zones during a number of expeditions with research ships Vema and Conrad (LDEO), Pillsbury and Gillis (University of Miami), Explora (OGS), Strakhov and Gelendzhik, operated by ISMAR-CNR, Italy. Details on acquisition and processing parameters can be found in Fabretti et al. [1998] and Bonatti et al. [1994a, 2005] for the Vema surveys, and in Bonatti et al. [1994b] and Gasperini et al. [1997a] for the Romanche surveys. Seismic reflection data obtained from the Vema and Romanche platforms have been reprocessed in order to carry out poststack depth migration. Poststack depth migration was achieved by a finite difference approximation to the wave equation, using acoustic velocities derived from analysis of reflected/refracted arrivals by fitting $P$ wave amplitudes and arrival times of recorded shot gathers with those of synthetic gathers obtained by forward two-points ray tracing [Cerveny et al., 1988]. Additional sequences were 
applied to remove bottom surface multiples using a 2-D surface-related multiple elimination (SRME) technique and adaptive filters; and to attenuate random and coherent noise, by filtering in the common shot, offset, receiver domains as well as f-k and tau-p domains.

[5] Data for Atlantis Bank were obtained on site surveys for ODP and IODP Legs 118 and 176. These included dredging, magnetics, narrow beam echo sounding and the Canadian ROV ROPOS from the British Antarctic Survey ship James Clark Ross Cruise 31, and the British Geologic Survey diamond coring drills. The Japanese Agency for Marine-Earth Science and Technology RV Yokosuka deployed the DSRV Shinkai 6500 on two cruises (MODE98 Leg 4 and Cruise YK01-14) and RV Kaire deployed the ROV Kaiko (MODE 2000 Leg 4).

[6] Spatial analysis and mapping were performed using the GMT [Wessel and Smith, 1998] and PLOTMAP [Ligi and Bortoluzzi, 1989] packages.

\subsection{Facies Analysis}

[7] Facies analyses were carried out by macroscopic and binocular microscope examination of carbonate samples and by thin section studies under the petrographic microscope.

\subsection{Strontium Isotope Analysis}

[8] Ages of the carbonates were estimated by $\mathrm{Sr}$ isotopes measured by thermal ionization mass spectrometry (TIMS) and multi-Collector inductively coupled plasma mass spectrometry (MCICPMS). Carbonate chips (35-70 mg) chosen from the interior, least altered parts of the sample, were handpicked and mechanically cleaned using a dental drill in order to remove fine-grained sediments or other visible contaminants. The subsamples were inspected under a binocular microscope and then crushed into a powder with an agate mortar and pestle.

\subsubsection{TIMS}

[9] The majority of the samples (28) were transferred to acid-cleaned bullets and rinsed three times with quartz-distilled water and one time with methanol in ultrasonic bath. Powders were then leached with $0.05 \mathrm{~N} \mathrm{HCl}$. Bulk samples were dissolved in double distilled $3 \mathrm{~N} \mathrm{HNO}_{3}$ and $\mathrm{Sr}$ was separated using standard ion exchange techniques, using Eichrom Sr-SPEC resins. Sr isotopes were measured by dynamic multicollection on a VG 54 TIMS at Lamont-Doherty Earth Observatory. The
${ }^{87} \mathrm{Sr} /{ }^{86} \mathrm{Sr}$ ratios were normalized to a stable isotopic ${ }^{86} \mathrm{Sr} /{ }^{88} \mathrm{Sr}$ ratio of 0.1194 and corrected for machine bias to an NBS-987 value of $0.71024 \pm 0.00004$ [Terakado et al., 1988]. Separate analyses of NBS-987 standard gave a mean ${ }^{87} \mathrm{Sr} /{ }^{86} \mathrm{Sr}$ value of $0.710264 \pm 0.000016(2 \sigma$, $n=25$, corresponding to an external reproducibility of $22 \mathrm{ppm})$.

\subsubsection{MC-ICP-MS}

[10] The remaining 19 samples were rinsed three times with MilliQ water in acid-cleaned bullets before leaching with $0.3 \%$ acetic acid to remove $30-40 \%$ of $\mathrm{CaCO}_{3}$. This first leaching step is designed to remove ions from exchangeable or leachable sites on the mineral surfaces. The remaining material was rinsed with MilliQ water and leached again with $0.4 \%$ acetic acid to remove $30 \%$ of $\mathrm{CaCO}_{3}$ for analysis, following a procedure by Li et al. [2011]. The supernatant solutions were evaporated and adjusted to $3 \mathrm{~N} \mathrm{HNO}_{3}$ for ion exchange chromatography. The solutions were loaded into $300 \mu \mathrm{l}$ columns containing 100-150 $\mu \mathrm{m}$ bead size Eichrom Sr-SPEC resin to remove matrix and isolate $\mathrm{Sr}$ from the interfering elements $\mathrm{Ca}, \mathrm{Rb}, \mathrm{REE}$. The columns were preflushed with 1 $\mathrm{ml} 3 \mathrm{~N} \mathrm{HNO}_{3}$ and $3 \mathrm{ml}$ MilliQ-water and conditioned using $1 \mathrm{ml} 3 \mathrm{~N} \mathrm{HNO}_{3}$. Strontium was eluted from the columns with $2.5 \mathrm{ml}$ MilliQ-water and each solution was adjusted to $0.5 \mathrm{~N} \mathrm{HNO}_{3}$ for elemental and isotopic measurements.

[11] Strontium isotope ratios were measured using the MC-ICPMS ThermoScientific Neptune ${ }^{\text {Plus }}$ at LSCE (Gif-sur-Yvette, France). Prior to the extraction of $\mathrm{Sr}$ for isotopic analysis a small aliquot of each sample solution was analyzed for $\mathrm{Ca}$, $\mathrm{Sr}, \mathrm{Rb}$, and REE concentrations using a quadrupole ICP-MS (Xseries ${ }^{\mathrm{II}}$ Thermo Fisher Scientific). $\mathrm{The} \mathrm{Ca} / \mathrm{Sr}$ mass ratios ranged between 40 and 1800. After chemistry, $\mathrm{Ca} / \mathrm{Sr}$ mass ratios were reduced to $0.8-1.2$ and $\mathrm{Rb}$ concentrations were systematically below the detection limit. All the solutions were then diluted to $50 \mathrm{ppb} \mathrm{Sr}$ and introduced into the Neptune using an ESI-APEX desolvating system and a $100 \mu \mathrm{l} / \mathrm{min}$ nebulizer. The sensitivity for $50 \mathrm{ppb} \mathrm{Sr}$ solution was $7 \mathrm{~V}$ on ${ }^{88} \mathrm{Sr}$ peak and the blank level $\left(0.5 \mathrm{~N} \mathrm{HNO}_{3}\right)$ was 0.01 $\mathrm{V}$. The samples and standards were analyzed in a static multicollection mode in a single block of 50 cycles with an integration time of $8 \mathrm{~s}$ per cycle. The instrumental mass fractionation was corrected for by using a stable isotopic ${ }^{86} \mathrm{Sr} /{ }^{88} \mathrm{Sr}$ ratio of 0.1194 and an exponential law. The efficient chromatographic purification eliminated most of the $\mathrm{Ca}(\mathrm{Ca} / \mathrm{Sr}$ ratio $0.8-1.2)$ and $\mathrm{Rb}$. No isobaric 
a)

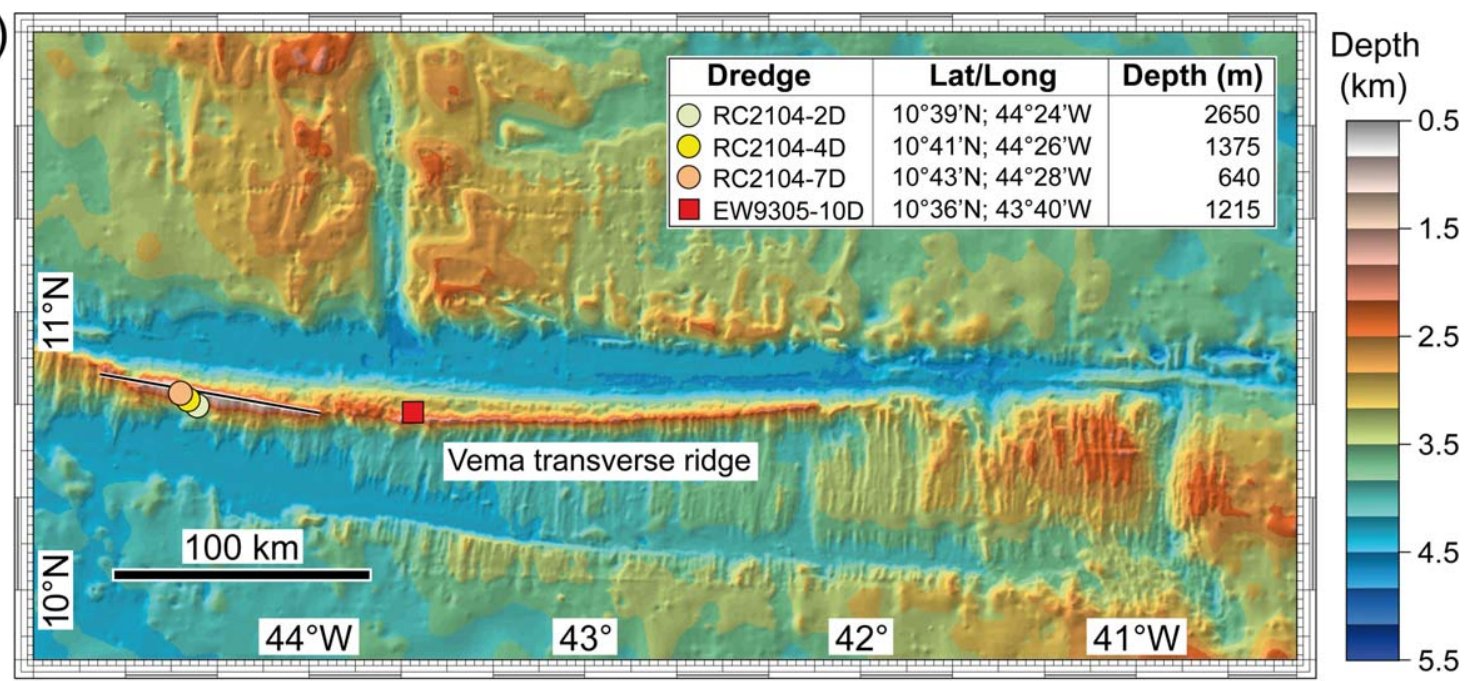

b)

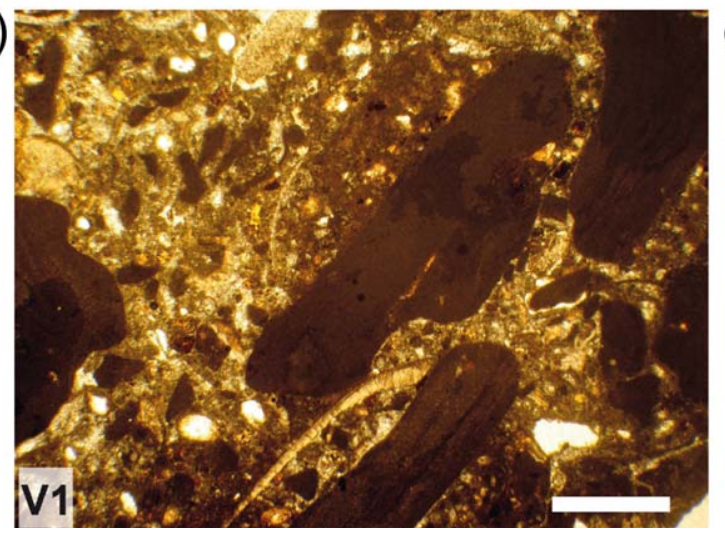

c)

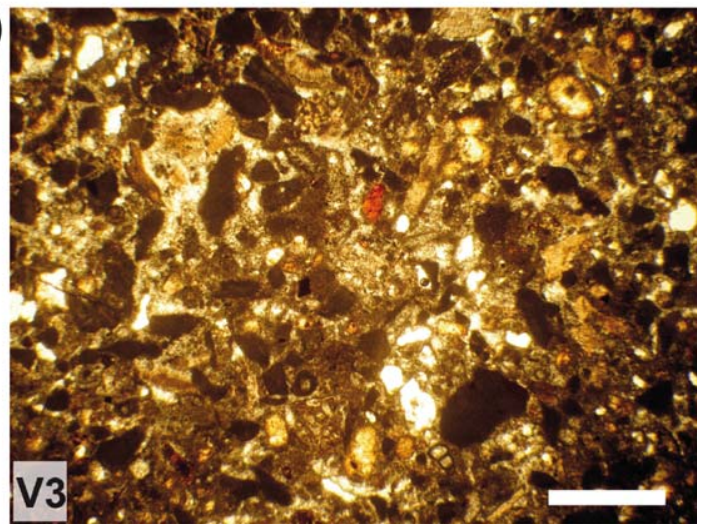

Figure 2. The Vema transform fault and photomicrographs of limestone samples from the Vema transverse ridge. (a) Bathymetry of the Vema region, data from Bonatti et al. [2003]. Red square and circles indicate locations of studied samples. Black solid line marks location of the multichannel seismic line VEMA-02, shown in Figure 3. (b) Facies V1: red-algae floatstone with fine-grained bioclastic matrix. (c) Facies V3: moderately well-sorted bioclastic packstone rich in red-algae fragments. Scale bar $=1 \mathrm{~mm}$.

corrections for $\mathrm{Ca}$ dimers and argides were required and only minor corrections for ${ }^{87} \mathrm{Rb}$ to ${ }^{87} \mathrm{Sr}$ were considered. A correction was also applied for krypton isobaric interferences. The effects of double charged REE on the $\mathrm{Sr}$ isotope masses were not considered due to the very low absolute REE abundances in the carbonates and the chromatographic purification. Repeated measurements of strontium isotope standard NBS-987 during the analytical session yielded a mean ${ }^{87} \mathrm{Sr} /{ }^{86} \mathrm{Sr}$ value of $0.710269 \pm 0.000014(2 \sigma \mathrm{SD}$, $n=19$, corresponding to an external reproducibility of $20 \mathrm{ppm})$. The ${ }^{87} \mathrm{Sr} /{ }^{86} \mathrm{Sr}$ ratio for all the samples was corrected for instrumental bias to an accepted value for NBS-987 of $0.71024 \pm 0.00004$ [Terakado et al., 1988]. All the ${ }^{87} \mathrm{Sr} /{ }^{86} \mathrm{Sr}$ ratios were converted into numerical ages using the regression curves LOWESS look-up table version 4: 08/04 [revised from McArthur et al., 2001].

\section{Results}

\subsection{Sunken Island at the Vema Transform}

[12] The Mid-Atlantic Ridge is offset at $11^{\circ} \mathrm{N}$ by the $\sim 320 \mathrm{~km}$ long Vema transform (Figure 2a). A $\sim 5 \mathrm{~km}$ deep transform valley is filled by over 1 $\mathrm{km}$ thick horizontally stratified turbidite deposits of probable South American derivation (DSDP Sites 216 and 353). A transverse ridge runs parallel to the transform on its southern side (Figure $2 a)$; it consists of a sliver of flexured and uplifted oceanic lithosphere [Bonatti et al., 2003, 2005]. Multichannel seismic reflection profiles along the summit of the transverse ridge imaged on its western, shallowest portion a strong horizontal reflector (Reflector B) extending along the crest for roughly $50 \mathrm{~km}$ (Figure $3 \mathrm{a}$ ). This reflector is capped by a $\sim 500 \mathrm{~m}$ thick unit. The unit above Reflector 

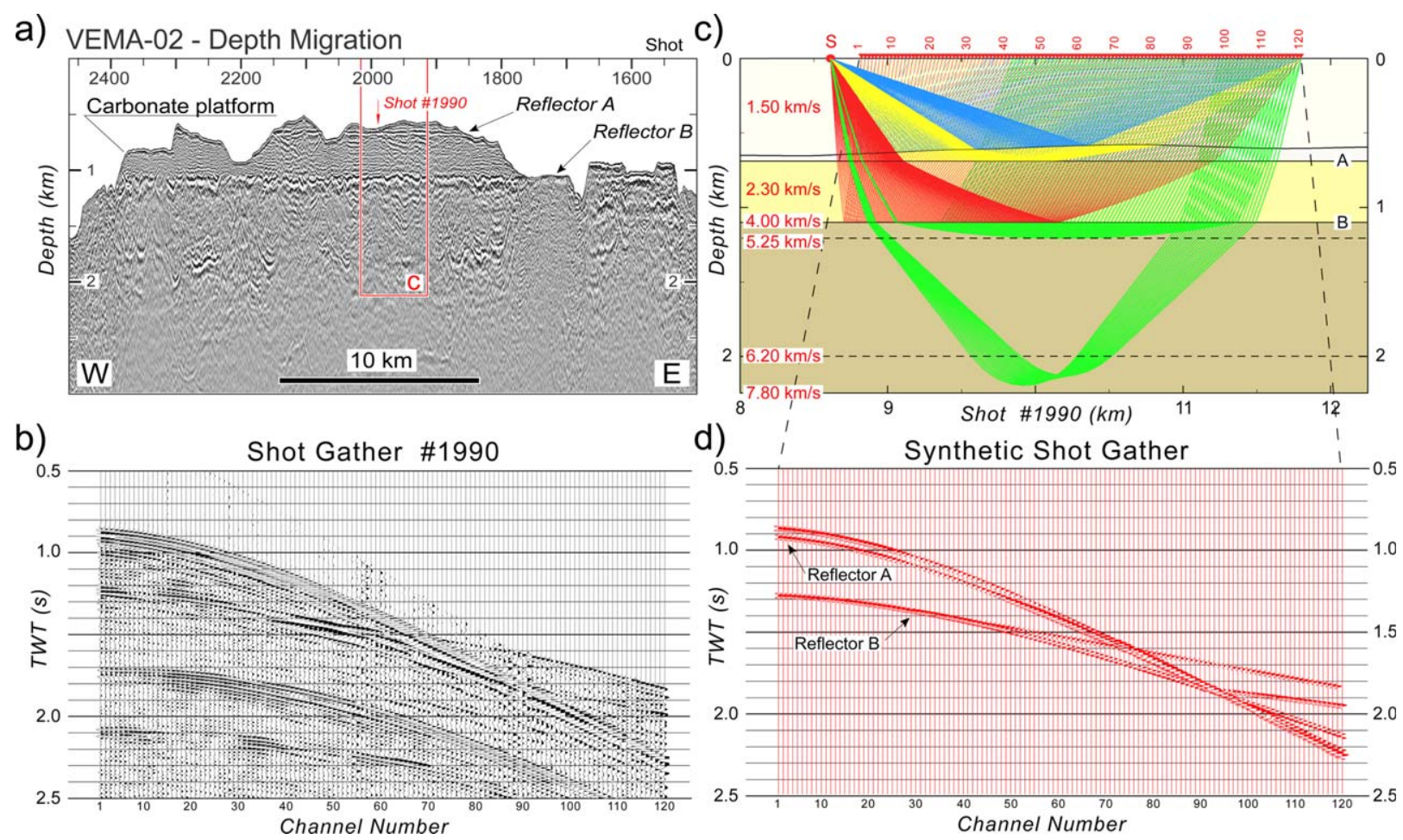

Figure 3. (a) Depth migrated seismic line VEMA-02 running along the crest of the Vema transverse ridge. The velocity model used in the poststack depth migration has been obtained constraining $P$ wave velocities by forward modeling. Ray-tracing modeling suggests that most of the oceanic upper crust has been eroded with lower crustal gabbro/dolerite and mantle peridotites very close to the base of limestones (Reflector B). Labeled red box indicates location of geological model in Figure 3c. (b) Recorded shot gather. (c) Geological model, seismic velocities, and ray paths. Two-point ray tracing boundary problem was solved by using paraxial rays in Cartesian coordinates [Cerveny et al., 1988]. Thick solid lines mark seismic reflectors; dashed lines mark layer boundaries with vertical gradient of seismic velocities. (d) Synthetic shot gather.

B gives acoustic velocities in the range $2-3 \mathrm{~km} / \mathrm{s}$, consistent with carbonate rocks. The seismic profile shows stratification above Reflection $\mathrm{B}$ and a rather incoherent pattern below it (Figure 3a), suggesting that Reflector B corresponds to the interface between the limestones and the top of the oceanic crust, an interpretation confirmed by extensive sampling [Bonatti et al., 1983, 1994a]. Acoustic velocities jump to $\sim 4 \mathrm{~km} / \mathrm{s}$ immediately below Reflector B, in line with the prevalence of upper crustal basalts. They then increase close to $5.25 \mathrm{~km} / \mathrm{s} \sim 200 \mathrm{~m}$ below Reflector B, consistent with the dominance of lower crustal doleriticgabbroic rocks (Figure 3).

[13] Seismic reflection data and the study of carbonate samples suggest that: (a) horizontal Reflector B represents a surface where the top of the basaltic oceanic crust was eroded and truncated at a former sea level. This implies that the summit of the Vema transverse ridge emerged at some stage in the past above sea level, i.e., formed an island; (b) the unit above Reflector B represents a 400$500 \mathrm{~m}$ thick carbonate platform, that grew on the eroded surface during subsidence; (c) an horizontal reflector (Reflector A) observed within the carbonate platform roughly $100 \mathrm{~m}$ below the top (Figure 3a), suggests that the growth of the platform was interrupted by a second younger sea level erosional event, possibly caused by eustatic sea level changes superimposed on lithospheric thermal subsidence. Reconstructions of sea level changes [Haq et al., 1987; Abreu and Anderson, 1998] show a strong sea level drop within the 12-10 Ma time interval, i.e., within the $\mathrm{Sr}$ isotopic age range for the Vema carbonate platform; (d) ray tracing forward modeling (Figure 3) suggests that the thickness of the upper basaltic crust below erosional surface B is reduced to $\sim 200 \mathrm{~m}$ due probably to mostly subaerial erosion of the upper $\sim 1 \mathrm{~km}$ of basaltic crust; consequently, lower crustal units (dyke complex and gabbros) are found close to the top of the igneous section; (e) a 
$10 \mathrm{~km}$ long stretch of horizontal Reflector B was detected on the crest of the Vema transverse ridge roughly $2 \mathrm{~km}$ east of the eastern edge of the main portion of the reflector (Figure 3a). This short stretch of Reflector B is not capped by a carbonate unit but lies close to the present day seafloor. It probably represents the erosional surface of a small fragment of upper oceanic crust, i.e., a former small island that emerged to the east of the longer Vema island.

\subsubsection{Vema Carbonate Platform: Facies Analysis} [14] Facies analysis and age determinations of samples obtained before 1983 are in Bonatti et al. [1983]. Following restudy of some of the old samples and of a study of new post-1983 cruise samples, we recognized six main facies (Table 1). Facies V1 (Figure 2b) and V2 have been recovered from the western portion of the Vema platform; facies V1, V3 (Figure 2c), V4, and V5 from the eastern portion of the platform; facies V1 and V6 from the central part of the platform. Samples from different sites along the Vema carbonate platform, although characterized by different textures, are dominated by the same biota assemblages, i.e., perforate larger benthic foraminifera, red algae, and rare corals. No real reef facies have been recognized. We suggest a ramp or a flattopped shelf geometry for the platform.

[15] Nannofossil calcareous biostratigraphy on three samples gives ages older than 9.4 Ma and 2 $\mathrm{Ma}$ (see online supporting information ${ }^{1}$ ).

[17] The occurrence in the western part of the platform of sedimentary dykes filled by shallow-water carbonates and the intense dissolution of calcitic Miogypsina tests provide evidence of fresh water diagenesis, suggesting subaerial exposure. The emergence of the platform was accompanied and/ or followed by tensional cracking, fissuring, and leaching of the early consolidated limestones. Subsequent shallow-water skeletal deposits (related to subsidence and/or sea-level rise) penetrated the tensional cracks and dykes. The horizontal seismic Reflector A, identified within the carbonate platform, probably records this emergence episode (Figure 3a).

\subsubsection{Sr Isotopic Ages of Vema's Limestones}

[18] We took advantage of the temporal variations of seawater ${ }^{87} \mathrm{Sr} /{ }^{86} \mathrm{Sr}$ ratio [Edmond, 1992] to estimate the age of the Vema carbonates. The ratio

\footnotetext{
${ }^{1}$ Additional supporting information may be found in the online version of this article.
}

${ }^{87} \mathrm{Sr} /{ }^{86} \mathrm{Sr}$ was determined in a number of carbonate samples, and the corresponding ages were derived from regression curves of McArthur et al. [2001] and McArthur and Howarth [2004]. Given possible postdepositional recrystallization of the carbonates, as well as possible admixture with carbonates younger than the original platform phases, we surmise that the oldest calculated ages are closest to the real age of the platform. The maximum ages fall around $11 \mathrm{Ma}$ (Table 2). This age is close to the age estimated for the transtensional flexure and uplift event of a lithospheric slab at the southern side of the Vema transform [Bonatti et al., 2005].

\subsection{Sunken Islands at the Romanche Transform}

[19] The Mid-Atlantic Ridge is offset near the equator by the $\sim 950 \mathrm{~km}$ Romanche transform, the longest transform of the entire mid-ocean ridge system (Figure 4a). Given its length and slip rate, the age contrast at the ridge/transform intersections is close to $50 \mathrm{Ma}$. The transform deformation zone is peculiar in so far as it is lens shaped with an up to $120 \mathrm{~km}$ width [Ligi et al., 2002]. This wide and complex transform deformation zone, contrasting with the narrow (a few kilometers) deformation zone observed in most oceanic transforms, has led to the concept of oceanic "megatransforms" [Ligi et al., 2002]. A prominent "transverse ridge" runs E-W parallel to the transform in the African plate opposite to the eastern ridge/transform intersection; it extends outside the active transform on the northern side of the aseismic fracture zone (Figure $4 \mathrm{a}$ ). The transverse ridge probably originated from flexure and uplift of slivers of oceanic lithosphere originally generated at the western segment of the Mid-Atlantic Ridge. Given a half spreading rate of $16 \mathrm{~mm} / \mathrm{a}$ [Cande et al., 1988], the age of this portion of the transverse ridge basaltic crust is over $50 \mathrm{Ma}$, with some uncertainty due to temporal variations of spreading rate and offset length, as well as to possible migrations of the transform boundary. Transpressive deformation may also have played a role in shaping the Romanche transverse ridge, as suggested by folding and thrusting observed in lower Cretaceous to Eocene deposits immediately $\mathrm{E}$ of the eastern ridge-transform intersection [Bonatti et al.,1996; Gasperini et al., 2001].

[20] The summit of this portion of the transverse ridge reaches $\sim 875 \mathrm{~m}$ below sea level, a roughly 4 $\mathrm{km}$ topographic anomaly relative to the oceanic 
Table 1. Carbonate Facies of the Vema, Romanche, and Atlantis Bank Carbonate Platforms

\begin{tabular}{|c|c|c|c|c|}
\hline Platform & Sample & Facies & Texture and Components & Environment \\
\hline \multirow[t]{20}{*}{ Vema } & RC2104-4D/A & \multirow[t]{8}{*}{ V1 } & \multirow{8}{*}{$\begin{array}{l}\text { Floatstone-rudstone dominated by red algae and } \\
\text { larger (Amphistegina) and small benthic forami- } \\
\text { nifera. Corals are rare. Cracks and sedimentary } \\
\text { dykes are present. }\end{array}$} & \multirow{8}{*}{$\begin{array}{l}\text { Moderate to deeper } \\
\text { parts of the photic } \\
\text { zone (inner-middle } \\
\text { ramp) }\end{array}$} \\
\hline & $\mathrm{RC} 2104-4 \mathrm{D} / \mathrm{B}$ & & & \\
\hline & $\mathrm{RC} 2104-4 \mathrm{D} / \mathrm{C}$ & & & \\
\hline & $\mathrm{RC} 2104-4 \mathrm{D} / \mathrm{A} 1$ & & & \\
\hline & RC2104-4D/B1 & & & \\
\hline & $\mathrm{RC} 2104-4 \mathrm{D} / \mathrm{C} 1$ & & & \\
\hline & RC2104-4D/C2 & & & \\
\hline & EW9305-10D/1D & & & \\
\hline & RC2104-2D/A & \multirow[t]{2}{*}{$\mathrm{V} 2$} & \multirow{2}{*}{$\begin{array}{l}\text { Pebbly mudstone with planktonic foraminifera, ben- } \\
\text { thonic skeletal debris with carbonate clasts (often } \\
\text { bioeroded) and volcanic clasts. }\end{array}$} & \multirow[t]{2}{*}{ Platform slope } \\
\hline & $\mathrm{RC} 2104-7 \mathrm{D} / \mathrm{A}$ & & & \\
\hline & EW9305-10D/3 & \multirow[t]{2}{*}{ V3 } & \multirow{2}{*}{$\begin{array}{l}\text { Well-sorted bioclastic packstone, mostly repre- } \\
\text { sented by red-algae fragments, with occasional } \\
\text { floating rhodoliths and fragments of Porites. }\end{array}$} & \multirow[t]{2}{*}{ Inner ramp } \\
\hline & $\begin{array}{l}\text { Sedimentary-dike in: } \\
\text { EW9305-10D/1D }\end{array}$ & & & \\
\hline & EW9305-10D/3 & \multirow[t]{2}{*}{ V4 } & \multirow{2}{*}{$\begin{array}{l}\text { Oncoidal wackestone with planktonic foraminifera } \\
\text { exhibiting frequent incipient coatings. Isopacous } \\
\text { and meniscus cement. Intense micritization. }\end{array}$} & \multirow[t]{2}{*}{ Subtidal-intertidal } \\
\hline & EW9305-10D/1C & & & \\
\hline & EW9305-10D/11 & \multirow[t]{4}{*}{ V5 } & \multirow{4}{*}{$\begin{array}{l}\text { Wackestone-packstone with planktonic foraminif- } \\
\text { era. Not completely lithified. }\end{array}$} & \multirow[t]{4}{*}{ Pelagic environment } \\
\hline & EW9305-10D/5 & & & \\
\hline & EW $9305-10 \mathrm{D} / 1 \mathrm{~A}$ & & & \\
\hline & EW9305-10D/1B & & & \\
\hline & $\begin{array}{l}\mathrm{RC} 2104-7 \mathrm{D} / \text { coral } \\
\mathrm{RC} 2104-7 \mathrm{D} / \text { bivalve }\end{array}$ & \multirow[t]{2}{*}{ V6 } & \multirow{2}{*}{$\begin{array}{l}\text { Cold-water coral assemblage formed by the aherma- } \\
\text { typic scleractinian coral Madrepora oculata in } \\
\text { association with the symbiotic polychaete Eunice } \\
\text { sp., and gorgonian deep-water corals (unidentified } \\
\text { species). }\end{array}$} & $\begin{array}{l}\text { Re-colonization of the } \\
\text { platform in the }\end{array}$ \\
\hline & EW9305-10D/3-coral & & & $\begin{array}{l}\text { bathyal zone during } \\
\text { the last } \\
\text { deglaciation }\end{array}$ \\
\hline Romanche A & $\mathrm{P} 6707-8 / 1 \mathrm{~A}$ & RA1 & Oolitic grainstone with subordinate echinoids. Good & Mobile shoal \\
\hline & P6707-8/1B & & sorting and cross laminations. Alternating lami- & \\
\hline & $\mathrm{P} 6707-8 / 1 \mathrm{C}$ & & nae separated by microbial mats. Ooids are & \\
\hline & P6707-8/2 & & mostly superficial, their nuclei are frequently & \\
\hline & P6707-8/3 & & planktonic foraminifera tests. Under SEM, they & \\
\hline & P6707-8/4 & & show aragonite needles with long axes mostly & \\
\hline & P6707-8/5A & & tangentially oriented. & \\
\hline & $\mathrm{P} 6707-8 / 5 \mathrm{~B}$ & & & \\
\hline & $\mathrm{P} 6707-8 / 6 \mathrm{~A}$ & & & \\
\hline & P6707-8/6B & & & \\
\hline & P6707-8/10 & & & \\
\hline & P6707-8/11 & & & \\
\hline & P6707-8/12 & & & \\
\hline & P6707-8/12B & & & \\
\hline & P6707-8/13A & & & \\
\hline & P6707-8/XA & & & \\
\hline & P6707-9/SL1 & RA2 & Wakestone-packstone with ooids, coated grains and & Inter-subtidal with ep- \\
\hline & P6707-8/1 & & larger foraminifera. Irregular vugs related to & isodic exposure \\
\hline & P6707-8/2 & & chemical leaching. & fringe \\
\hline & P6707-8/9 & & & \\
\hline & P6707-8/13 & & & \\
\hline & P6707-8/A & & & \\
\hline & P6707-8/B & & & \\
\hline & $\mathrm{P} 6707-8 / \mathrm{C}$ & & & \\
\hline & P6707-8/XB & & & \\
\hline Romanche A & P6707-8/7 & RA3 & $\begin{array}{l}\text { Packstone with planktonic foraminifera and with } \\
\text { carbonate and volcanic lithoclasts. }\end{array}$ & Platform slope \\
\hline & $\mathrm{P} 6707-8 / \mathrm{S} 9$ & RA4 & Poorly lithified planktonic-rich limestones. & Pelagic environment \\
\hline Romanche C & $\mathrm{S} 16-62 / 3$ & $\mathrm{RC} 1$ & Floatstone-rudstone-framestone with corals (Pori- & Platform margin \\
\hline & S16-62/5 & & tes) and with red algae and larger foraminifera. & \\
\hline & S16-62/6 & & Fringes of isopachous cement with residual & \\
\hline & S16-53/13 & & porosity. & \\
\hline & S16-53/14A & & & \\
\hline & $\mathrm{S} 16-53 / 2$ & $\mathrm{RC} 2$ & Packstone-floatstone to wackestone with larger fora- & Inner ramp (tempo- \\
\hline & S16-62/13a & & minifera (Miogypsina, Amphistegina) and coral & rary exposure)? \\
\hline & S16-62/13b & & fragments. Intense leaching of calcitic Miogyp- & \\
\hline & S16-62/13b1 & & $\begin{array}{l}\text { sina tests, reddish micrite intraparticle-porosity } \\
\text { infilling. }\end{array}$ & \\
\hline & $\mathrm{S} 16-53 / 2$ & $\mathrm{RC} 3$ & Peloidal wackestone-packstone with rare benthonic & Inter-tidal \\
\hline
\end{tabular}


Table 1. (continued)

\begin{tabular}{|c|c|c|c|c|}
\hline Platform & Sample & Facies & Texture and Components & Environment \\
\hline & & & $\begin{array}{l}\text { stromatolite-like laminae. Neptunian dykes are } \\
\text { present. }\end{array}$ & \\
\hline & $\mathrm{S} 16-62 / 2$ & $\mathrm{RC} 4$ & Oncoidal wackestone-packstone with bio- & Inter-subtidal (tempo- \\
\hline & S16-62/8 & & lithoclasts. Micritization and irregular leaching & rary exposure) \\
\hline & S16-62/11 & & derived cavities are common features. & \\
\hline & S16-62/12 & & & \\
\hline & S16-53/4 & RC5 & $\begin{array}{l}\text { Rudstone-floatstone rich in planktonic foraminifera } \\
\text { and with bioclasts and carbonate lithoclasts. }\end{array}$ & Platform slope \\
\hline \multirow[t]{20}{*}{ Atlantis Bank } & JR31-34/4a & AT1 & Floatstone-rudstone with coarse-grained bryozoan- & Deep platform within \\
\hline & JR31-34/4b & & echinoid fragment and with benthic foraminifera & the current action \\
\hline & JR31-34/4c & & (mostly lagenids). & \\
\hline & JR31-34/a & AT2 & Skeletal wackestone-packstone with abundant & Deep platform below \\
\hline & JR31-34/b & & planktonic foraminifera, benthonic foraminifera & the current action \\
\hline & JR31-34/c & & (lagenids, miliolids, anomalinids), and bryozoan- & \\
\hline & JR31-34/d & & echinoid fragments. & \\
\hline & JR31-24/1 & AT3 & Planktonic-rich packstone with gravel-sized skeletal & Platform-edge slope \\
\hline & JR31-24/15 & & fragments of bryozoans, mollusks and larger & \\
\hline & JR31-32/8 & & foraminifera. & \\
\hline & JR31-32/10 & & & \\
\hline & JR31-32/17 & & & \\
\hline & JR31-32/18 & & & \\
\hline & JR31-35/5 & & & \\
\hline & JR31-35/6 & & & \\
\hline & JR31-45/2 & AT4 & Poorly lithified packstone-wackestone with plank- & Deep slope \\
\hline & JR31-37/1 & & tonic foraminifera and fine-grained benthic skele- & \\
\hline & JR31-37/3 & & tal debris. & \\
\hline & JR31-37/4 & & & \\
\hline & JR31-32/9 & & & \\
\hline
\end{tabular}

lithosphere thermal subsidence curve. Multichannel seismic reflection profiles taken along the crest of the transverse ridge revealed three elevated, roughly $50 \mathrm{~km}$ long segments, each underlain by a strong horizontal reflector, capped by units that, based on sampling, consist of carbonate platforms [Bonatti et al., 1994b; Gasperini et al., 1997b]. They have been identified from $\mathrm{W}$ to $\mathrm{E}$ as Romanche sunken islands A, B, and C (Figure 5). Sampling of the slopes below Reflectors $\mathrm{R}_{1}$ (Paleoisland $\mathrm{A}$ ), $\mathrm{R}_{2}$ (Paleoisland $\mathrm{B}$ ), and $\mathrm{R}_{3}$ (Paleoisland $\mathrm{C}$ ) released oceanic basalts and dolerites, suggesting that the three horizontal reflectors represent surfaces of erosion at a sea level of the upper basaltic oceanic crust, that had been uplifted above sea level, forming three islands. Assuming a $P$ wave acoustic velocity of $2 \mathrm{~km} / \mathrm{s}$ for the limestones, a thickness ranging between 200 and $300 \mathrm{~m}$ can be estimated for the carbonate platforms.

[21] Paleoisland A (Figure 4b) is $\sim 32 \mathrm{~km}$ long in an $\mathrm{E}-\mathrm{W}$ direction and $\sim 6.5 \mathrm{~km}$ wide. It displays a $\sim 300 \mathrm{~m}$ thick carbonate platform; stratified sediments prograde westward from the platform, into a $\sim 5 \mathrm{~km}$ wide shallow basin bound to the west by a $\sim 70 \mathrm{~m}$ high and $\sim 450 \mathrm{~m}$ wide nontransparent relief that based on detailed morpho-bathymetry of Gasperini et al. [1997b] may represent a continuous bank within the main platform.
[22] Paleoisland B (Figure 4c) is the smallest (about $5 \mathrm{~km}$ wide), it has an irregular morphology probably determined in part by crustal erosional collapse. This relief shows a strong horizontal reflector $\left(\mathrm{R}_{2}\right)$ below an about $250 \mathrm{~m}$ thick carbonate platform.

[23] Paleoisland $\mathrm{C}$ has a very regular morphology (Figure 4d); it is about $25 \mathrm{~km}$ long (E-W), $1.5 \mathrm{~km}$ wide (N-S) and it displays a $\sim 300 \mathrm{~m}$ thick carbonate platform resting on horizontal reflector $\left(\mathrm{R}_{3}\right)$. Reflector $\mathrm{R}_{3}$ lies close to the seafloor at the eastern edge of the relief indicating a portion of erosional surface without a significant carbonate cap.

\subsubsection{Romanche Carbonate Platforms: Facies Analysis}

[24] Limestone samples recovered from Paleoislands $\mathrm{A}$ and $\mathrm{C}$ were studied already by Bonatti et al. [1977]. Based on a new study of these and other samples, we recognized eight main facies (Table 1 and Figure 5).

[25] The main biota components of the Romanche carbonate platforms are: perforate larger benthic foraminifera, red algae, and corals (mostly Porites). Significant additional components are ooids that show tangential aragonitic needles at the SEM. These components are similar to those observed at the Vema carbonate platform. Textures, structures, and biota assemblages suggest a rimmed shelf with a variety of facies from subtidal to intertidal and 
Table 2. Strontium Isotope Determinations of the Vema, Romanche, and Atlantis Bank Limestones ${ }^{\mathrm{a}}$

\begin{tabular}{|c|c|c|c|c|c|c|}
\hline Platform & Sample & Method & ${ }^{87} \mathrm{Sr} /{ }^{86} \mathrm{Sr}$ & Minimum age ${ }^{\mathrm{b}}$ & Mean age ${ }^{c}$ & Maximum age ${ }^{\mathrm{d}}$ \\
\hline \multirow[t]{18}{*}{ Vema } & RC2104-4D/A & TIMS & $0.708873(18)$ & 9.65 & 10.41 & 11.27 \\
\hline & $\mathrm{RC} 2104-4 \mathrm{D} / \mathrm{A}^{\mathrm{e}}$ & TIMS & $0.708851(18)$ & 10.30 & 11.18 & 12.45 \\
\hline & RC2104-4D/B & TIMS & $0.708847(17)$ & 10.48 & 11.34 & 12.59 \\
\hline & $\mathrm{RC} 2104-4 \mathrm{D} / \mathrm{B}^{\mathrm{e}}$ & TIMS & $0.708844(17)$ & 10.59 & 11.52 & 12.71 \\
\hline & RC2104-4D/C2 & MC-ICP-MS & $0.708897(15)$ & 8.91 & 9.7 & 10.37 \\
\hline & RC2104-4D/A1 & MC-ICP-MS & $0.708964(15)$ & 6.21 & 6.66 & 7.4 \\
\hline & RC2104-4D/B1 & MC-ICP-MS & $0.708861(15)$ & 10.1 & 10.8 & 11.85 \\
\hline & RC2104-4D/C1 & MC-ICP-MS & $0.708884(15)$ & 9.42 & 10.06 & 10.74 \\
\hline & RC2104-2D/A & TIMS & $0.708993(17)$ & 5.68 & 6.01 & 6.39 \\
\hline & RC2104-7D/coral & TIMS & $0.709151(17)$ & 0.22 & 0.62 & 1.12 \\
\hline & RC2104-7D/bivalve & TIMS & $0.709177(17)$ & 0.00 & 0.00 & 0.00 \\
\hline & EW9305-10D/3-coral & TIMS & $0.709182(17)$ & 0.00 & 0.00 & 0.00 \\
\hline & EW9305-10D/3 & TIMS & 0.708844 (17) & 10.62 & 11.80 & 12.71 \\
\hline & EW9305-10D/1C & TIMS & 0.709095 (17) & 1.35 & 1.70 & 2.30 \\
\hline & EW9305-10D/1C & TIMS & $0.709090(17)$ & 1.42 & 1.82 & 2.45 \\
\hline & EW9305-10D/11 & TIMS & 0.709174 (17) & 0.00 & 0.00 & 0.00 \\
\hline & EW9305-10D/1A & TIMS & $0.708952(18)$ & 6.43 & 7.10 & 8.45 \\
\hline & EW9305-10D/1B & TIMS & $0.708971(18)$ & 6.03 & 6.45 & 7.20 \\
\hline \multirow[t]{17}{*}{ Romanche A } & $\mathrm{P} 6707-8 / 1^{\circ}$ & TIMS & $0.708938(17)$ & 6.90 & 7.64 & 9.12 \\
\hline & P6707-8/1B & TIMS & $0.708886(17)$ & 9.28 & 10.00 & 10.74 \\
\hline & P6707-8/1C & TIMS & $0.708985(15)$ & 5.85 & 6.13 & 6.56 \\
\hline & $\mathrm{P} 6707-8 / 1 \mathrm{C}^{\mathrm{e}}$ & TIMS & $0.708959(17)$ & 6.27 & 6.84 & 7.69 \\
\hline & P6707-8/5A & TIMS & 0.708964 (17) & 6.17 & 6.66 & 7.54 \\
\hline & P6707-8/5B & TIMS & 0.708969 (16) & 6.08 & 6.51 & 7.24 \\
\hline & P6707-8/6A & TIMS & $0.708941(17)$ & 6.79 & 7.52 & 8.97 \\
\hline & P6707-8/12B & TIMS & $0.708951(18)$ & 6.43 & 7.14 & 8.51 \\
\hline & P6707-8/13A & TIMS & 0.708937 (17) & 6.86 & 7.68 & 9.17 \\
\hline & P6707-8/A & TIMS & $0.708910(18)$ & 7.85 & 9.29 & 10.02 \\
\hline & P6707-8/B & TIMS & $0.708906(17)$ & 8.30 & 9.43 & 10.14 \\
\hline & P6707-8/C & TIMS & 0.708953 (17) & 6.40 & 7.07 & 8.35 \\
\hline & P6707-9/SL1 ${ }^{\text {f }}$ & TIMS & 0.709004 (19) & 5.33 & 5.82 & 6.18 \\
\hline & P6707-9/SL1 ${ }^{\text {f }}$ & TIMS & $0.708997(20)$ & 5.50 & 5.94 & 6.37 \\
\hline & P6707-9/SL1 ${ }^{\text {f }}$ & TIMS & $0.708989(18)$ & 5.71 & 6.07 & 6.53 \\
\hline & P6707-8/7 & TIMS & 0.708949 (17) & 6.53 & 7.22 & 8.56 \\
\hline & P6707-8/S9 & TIMS & $0.709177(17)$ & 0.00 & 0.00 & 0.00 \\
\hline Romanche C & S16-53/13 & TIMS & 0.708988 (17) & 5.75 & 6.09 & 6.50 \\
\hline \multirow[t]{15}{*}{ Atlantis Bank } & JR31-34/4 & MC-ICP-MS & $0.709066(16)$ & 2.02 & 2.67 & 4.53 \\
\hline & JR31-34/4c & MC-ICP-MS & $0.709081(12)$ & 1.653 & 2.15 & 2.64 \\
\hline & JR31-34/8 & MC-ICP-MS & $0.709067(15)$ & 2.02 & 2.63 & 4.39 \\
\hline & JR31-34/8c & MC-ICP-MS & $0.709076(13)$ & 1.77 & 2.30 & 2.99 \\
\hline & JR31-34/8a & MC-ICP-MS & 0.709085 (13) & 1.555 & 2.01 & 2.52 \\
\hline & JR31-34/8b & MC-ICP-MS & 0.709077 (13) & 1.77 & 2.27 & 2.87 \\
\hline & JR31-24/1 & MC-ICP-MS & $0.709019(15)$ & 4.95 & 5.52 & 5.87 \\
\hline & JR31-24/15 & MC-ICP-MS & 0.709043 (13) & 3.31 & 4.74 & 5.27 \\
\hline & JR31-32/8 & MC-ICP-MS & 0.709059 (13) & 2.37 & 3.28 & 4.73 \\
\hline & JR31-32/10 & MC-ICP-MS & $0.709053(15)$ & 2.48 & 4.01 & 5.01 \\
\hline & JR $31-32 / 10^{f}$ & MC-ICP-MS & $0.709045(13)$ & 3.07 & 4.65 & 5.17 \\
\hline & JR31-35/5 & MC-ICP-MS & $0.709155(12)$ & 0.231 & 0.629 & 0.953 \\
\hline & $\mathrm{JR} 31-35 / 5^{\mathrm{f}}$ & MC-ICP-MS & $0.709159(15)$ & 0.000 & 0.550 & 0.930 \\
\hline & JR31-37/3 & MC-ICP-MS & $0.709129(13)$ & 0.888 & 1.146 & 1.363 \\
\hline & JR31-45/2 & MC-ICP-MS & $0.708870(13)$ & 9.90 & 10.50 & 11.14 \\
\hline
\end{tabular}

${ }^{\text {a }}$ Data in parentheses represent the cumulative error, calculated by adding in quadrature $1 \sigma$ of each single run (internal error) and $2 \sigma$ of repeated measurements of the standard SMR 987 (external error).

${ }^{\mathrm{b}}$ Maximum age (Ma) obtained from the mean isotopic value $-2 \sigma$ (standard deviation) on the upper limit age curve.

${ }^{\mathrm{c}}$ Mean age (Ma) obtained from the mean isotopic value on the mean age curve.

${ }^{\mathrm{d}}$ Minimum age (Ma) obtained from the mean isotopic value $+2 \sigma$ on the lower limit age curve.

${ }^{\mathrm{e}}$ The filament was re-analyzed.

${ }^{\mathrm{f}} \mathrm{A}$ micro-portion of the same sample was processed and analyzed separately.

from the margin (both oolitic shoals and framestone fabric) up to the slope of the platform. No typical lagoon facies material was observed.

[26] The Romanche carbonate platforms record a prolonged period of exposure (documented by fresh-water diagenesis), nondeposition, and lithification. Subsequent extensional tectonics promoted fracturing and formation of neptunian dykes that were filled by new transgressive shallow-water sediments. Paleoislands A and C show contrasting facies distribution. Oolitic sands are dominant in 
a)

)$^{1 \circ} \mathrm{N}$

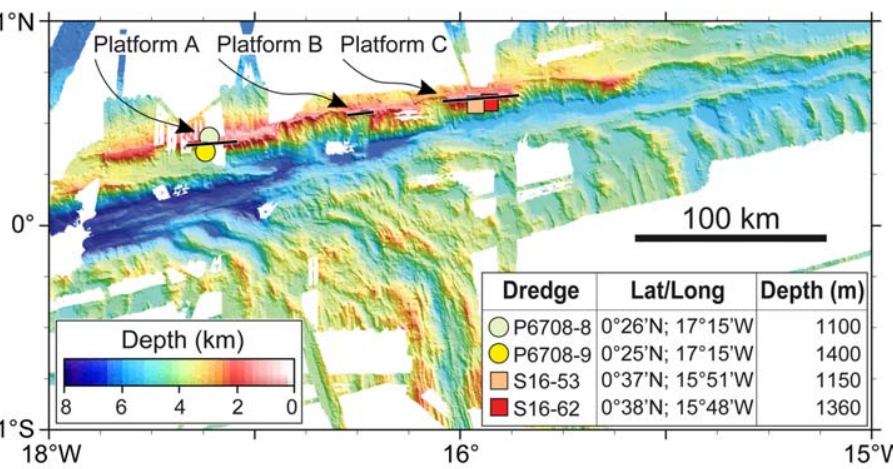

b) ROM-02MA - Depth migration

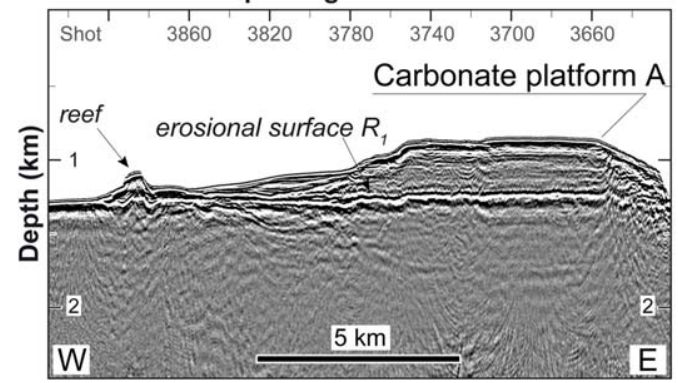

d) ROM-02MC - Depth migration

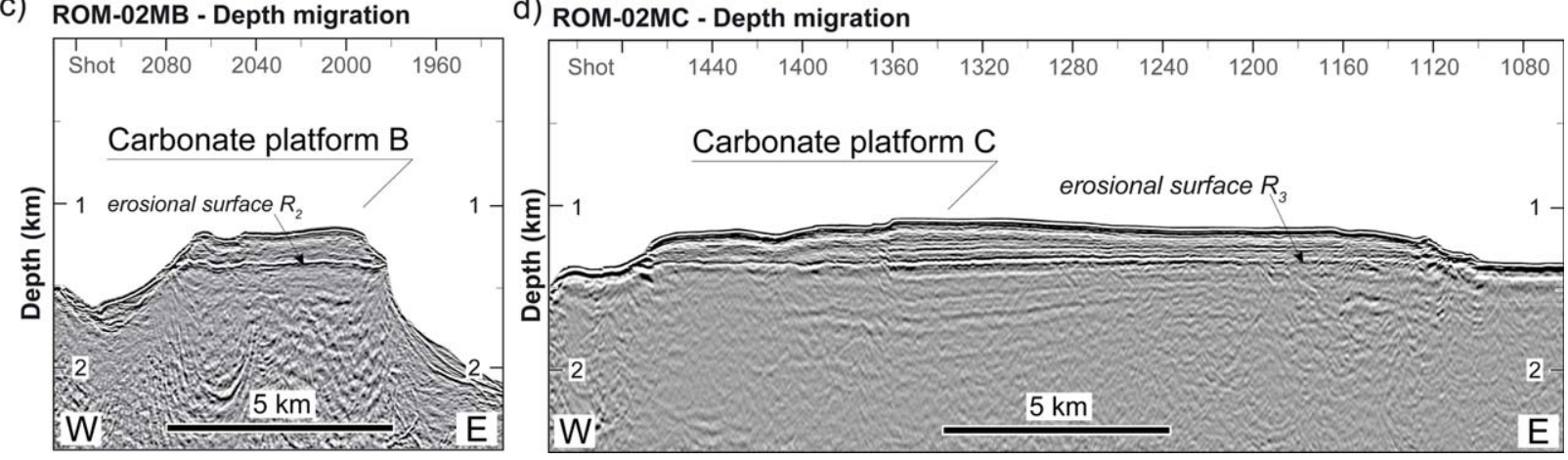

Figure 4. The Romanche Megatransform. (a) Multibeam bathymetry of the Romanche eastern ridgetransform intersection and of the northern transverse ridge obtained by merging our data [Gasperini et al., 1997a] with those of EQUAMARGE2, CONADAK, and ROMANCHE1 cruises (IFREMER). Circles and squares indicate locations of studied samples from Platform A and Platform C, respectively. Locations of multichannel seismic profiles (black lines) shown in Figures 4b, 4c, and 4d are also indicated; (b) seismic profile ROM-02MA (Paleoisland A); (c) ROM-02MB (Paleoisland B); and (d) ROM-02MC (Paleoisland C).

the westernmost Paleoisland A. Coated grains as observed on Paleoisland A occur normally when salinity exceeds $35.8 \%$ o [Lees, 1975]; thus, they are not common in carbonates from the equatorial region. The easternmost edge of Paleoisland $\mathrm{C}$, on the contrary, is rich in coral reef materials. The intense phosphatization of the oolitic facies and the unusual presence of planktonic foraminifera as nuclei of ooids suggest high water fertility, probably induced by upwelling currents [Hallock and Schlager, 1986]. Modern carbonate platforms show a significant influence of the prevailing wind directions on the type of carbonate production. Examples from the Atlantic Bahamian platforms [Gebelein, 1974] and from western Pacific platforms [Wilson and Vecsei, 2005] provide evidence that framework-built marginal reefs develop mostly on margins facing into the prevailing wind-related current direction. The Romanche sunken islands, lying in the belt of trade winds blowing persistently from the East, may be affected by strong upwelling of nutrient-rich deep waters on their western lee side, explaining the development of oolitic shoals on Paleoisland A. The oolitic sands, under the trade winds influence, underwent reworking and off-bank transport promoting deposition at the bank edge and its westward-prograding geometry. At the same time, persistent wind-generated wave action on the eastern side may have promoted mixing of the surface waters, helping the growth of patch reefs on Paleoisland C.

[27] Calcareous nannofossil biostratigraphy on four samples from Paleoisland A gives ages older than $3.8 \mathrm{Ma}$ and $0.46 \mathrm{Ma}$ (see online supporting information).

\subsubsection{Sr Isotopic Ages of Romanche's Limestones} $[28]{ }^{87} \mathrm{Sr} /{ }^{86} \mathrm{Sr}$ ratios measured in samples of Romanche carbonate Paleoisland A give an oldest age close to $\sim 10 \mathrm{Ma}$ (Table 2 ). Sr isotopic data are available for only one sample from Paleoisland $\mathrm{C}$, with a calculated age of $\sim 6 \mathrm{Ma}$ (Table 2).

\subsection{Sunken Island at the Atlantis II Transform}

[29] The Atlantis II transform offsets the ultraslow spreading Southwest Indian Ridge by about 200 $\mathrm{km}$ (Figure 6a). A deep transform valley is bordered by a $6 \mathrm{~km}$ high transverse ridge created by a 

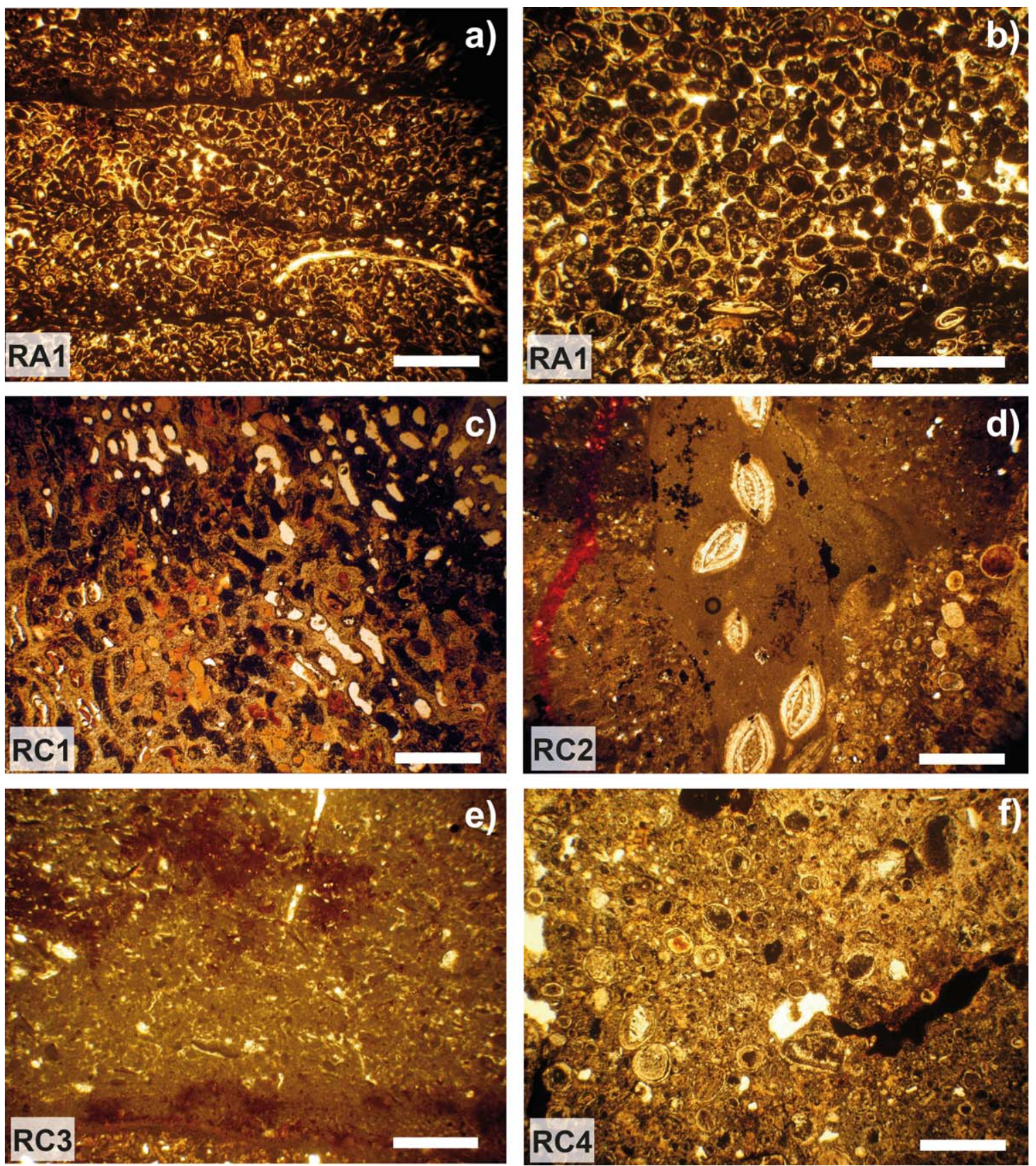

Figure 5. Photomicrographs of some carbonate facies of Romanche platforms. Facies RA1: (a) laminae of oolitic grainstone separated by microbial mats and (b) superficial ooids and coated grains with nuclei mostly made by planktonic foraminifera. (c) Facies RC1: coral framestone (Porites). (d) Facies RC2: neptunian dyke filled with Amphistegina rich wackestone. (e) Facies RC3: peloidal wackestone with desiccation shrinkage. (f) Facies RC4: oncoidal wackestone with leaching cavities. Scale bar $=1 \mathrm{~mm}$.

7.5 Ma long transtension phase due to a spreading direction change at $\sim 19.5$ Ma [Dick et al., 1999, Baines et al., 2003]. Atlantis Bank lies on this ridge reaching a minimum depth of $700 \mathrm{~m}$ close to the center of the transform offset. It is $100 \mathrm{~km}$ from the eastern ridge-transform intersection and has a crustal age of $\sim 11.3 \mathrm{Ma}$ [Dick et al., 2000].
The summit is a $25 \mathrm{~km}^{2}$ wave-cut platform with a total relief of $\sim 50 \mathrm{~m}$ with numerous low erosional haystacks clustered in its center surrounded by a smooth gently sloping terrace consisting of exposed gabbro-mylonite bedrock and carbonate beach sands [Dick et al., 1999]. The Ocean Drilling Program drilled 1504 m into Atlantis Bank, 
a)

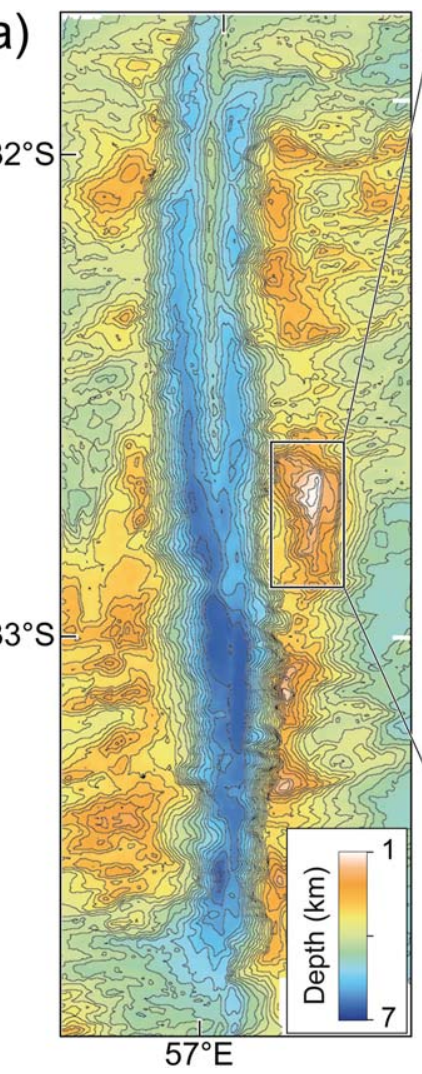

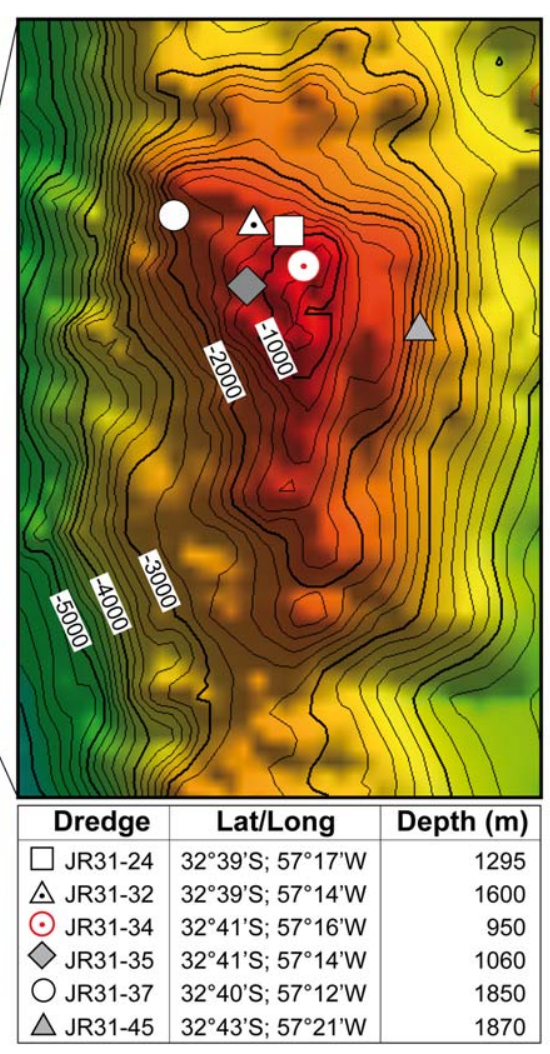

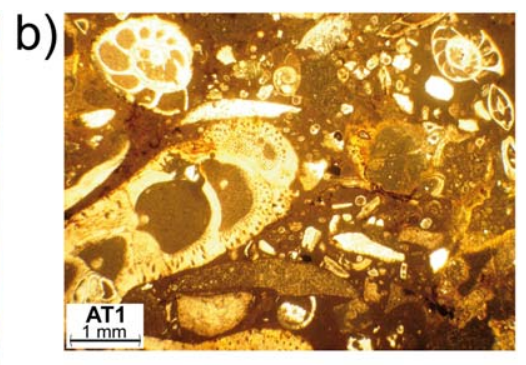

c)
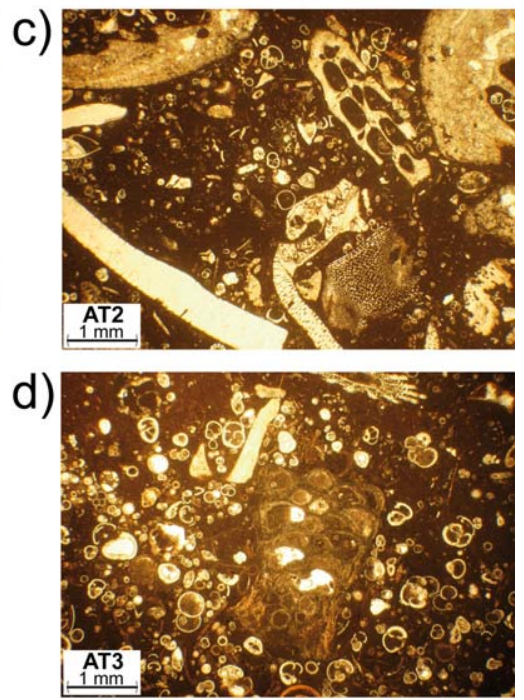

Figure 6. Atlantis II transform fault. (a) Bathymetry of the Atlantis II. Detailed bathymetry of the Atlantis Bank and dredge samples location are shown in the inset. (b) Photomicrographs of facies AT1: floatstonerudstone with bryozoan fragments and benthic foraminifera (lenticulinids, lagenids); (c) photomicrographs of facies AT2: skeletal floatstone with a wackestone matrix rich in planktonic foraminifera; (d) photomicrographs of facies AT3: planktonic packstone-wackestone with scattered coarse-grained bryozoan and echinoid fragments.

recovering $1308 \mathrm{~m}$ of gabbro and a single $0.5 \mathrm{~m}$ diabase dike from Hole 735B [Dick et al., 2000]. This confirmed that Atlantis Bank is an uplifted block of lower crust exposed in a large oceanic core complex [Natland and Dick, 2001]. The bank, due to the remarkable preservation of ancient shorelines and beaches, was named for the fabled island of Atlantis. Atlantis Bank, contrary to the other tectonic islands we have studied, has no carbonate platform due to its paleo and present position south of Darwin's carbonate line, where reef carbonates are not found [ Grigg, 1982].

\subsubsection{Atlantis Bank Carbonate Platform: Facies Analysis}

[30] A number of limestone samples were dredged from the summit of Atlantis Bank. Four main facies were identified based on sedimentary textures and biotic components (Table 1 and Figure 6). The most abundant biota components are bryozoans, mostly in the erect growth forms [in the sense of Nelson et al., 1988]. Mollusks are locally as abun- dant; benthonic foraminifera are ubiquitous (especially lagenids and miliolids; Figures $6 \mathrm{~b}$ and $6 \mathrm{c}$ ); planktonic foraminifera are also common and are dominant in muddy sediments (Figure 6d). Red algae are absent or present just as fine-grained fragments. Nonskeletal carbonate grains (e.g., ooids) as well as coral framestone are totally absent. This skeletal composition is commonly known as "foramol" and "molechfor" or, more generally, as a heterozoan association [in the sense of James, 1997], typical of temperate water carbonate deposits. It is consistent with Atlantis Bank being located within the southern warm temperate biogeographic province, roughly parallel to the equator, at approximately $30^{\circ} \mathrm{S}$ latitude. Sediments with bryozoan-dominated skeletal material are deposited in modern and tertiary carbonates from subtropical to temperate carbonate platforms in the Mediterranean realm [Nebelsik, 1989; Fornos and Ahr, 1997; Mutti et al., 1997; Corda and Brandano, 2003] as well as in southwestern Australia and New Zealand [Nelson et al., 1988; 
James et al., 1992] and in the US Mid-Atlantic coastal plain [Coffey and Read, 2007].

[31] The location of Atlantis Bank suggests similarity with the high-energy hydrodynamics off southern Australia rather than the relatively quiet waters of the Mediterranean Sea. In particular, the Lacepede shelf and the Rottnest shelf, along the southern and southwestern Australian continent [James et al., 1992, 1999], appear to be appropriate modern counterparts for the Atlantis Bank carbonates. These shelves are commonly swept by ocean swells that move sediments to depths of 140 $\mathrm{m}$. Above this depth (between 80 and $140 \mathrm{~m}$ ) bryozoan-rich sands dominate; below bryozoanrich muddy facies are prevalent [James et al., 1992].

[32] Based on texture and biotic components, the limestones from Atlantis Bank were deposited on a 100-200 $\mathrm{m}$ deep platform, both in a high-energy zone affected by strong waves and currents (testified by grain-supported textures, microfacies AT1; Table 1 and Figure 6b) as well as in a lowenergy environment, below the swell base, where skeletal fragments removed from shallower zones could accumulate together with muddy sediments (matrix-supported textures, microfacies AT2; Table 1 and Figure 6c). Strong currents affecting the Atlantis Bank carbonate platform may explain the large amount of gravel-sized skeletal debris swept from shallower areas into deeper zones and the slope. The swell base could have been the depth limit between high-energy and low-energy environments, explaining the high proportion of mud in a poorly sorted skeletal facies (AT3; Table 1 and Figure 6d). In analogy to observations by James et al. [1992], the shallow platform may have been a zone of minor carbonate accumulation, whereas the deeper shelf and slope could have represented a zone of active sediment accumulation.

[33] The scarcity absence of important calcareous phototrophs such as red algae, common in many nontropical carbonates, may indicate deposition under poorly lighted waters and under eutrophic conditions [Mutti and Hallock, 2003; Halfar and Mutti, 2005]. The Atlantis Bank carbonates may have been deposited within an open, deep platform characterized by poorly lighted waters with high nutrient levels caused by oceanic upwelling. A relatively deep and eutrophic environment is suggested also by: (a) the presence of deep benthonic foraminifera (such as lagenids); (b) the dominance of filter-feeding organisms such as bryozoans and echinoids; and (c) the abundance of planktonic foraminifera and the common occurrence of boring activity. Age determinations of some Atlantis Bank samples are constrained by planktonic assemblages (L. Di Bella, 2013 personal communications). Globorotalia margaritae, Globorotalia tumida, and Globorotalia gr. crassaformis occur in samples JR31-24/1 and JR31-24/15 suggesting a Zanclean age (early Pliocene) [Bolli and Saunders, 1989; Iaccarino et al., 2007] in agreement with $\mathrm{Sr}$ isotopic ages.

[34] Nannofossil calcareous biostratigraphy of seven samples gives ages ranging between middle Miocene to Pleistocene (see online supporting information).

\subsubsection{Sr Isotopic Ages of Atlantis Bank's Limestones}

[35] ${ }^{87} \mathrm{Sr} /{ }^{86} \mathrm{Sr}$ calculated ages measured in bulk and in isolated bioclastic fragments range between 4.5 and $2.3 \mathrm{Ma}$ (Table 2). These ages, significantly younger than the Atlantis Bank crustal age, show that the carbonate samples were deposited far from the ridge-transform intersection after the Bank sank below sea level.

\section{A Modern Example of Oceanic Tectonic Island: St. Peter-Paul Rocks}

[36] The islets of St. Peter and St. Paul are located in the equatorial Atlantic (Figure 1) along the St. Paul transform system, which offsets the MidAtlantic Ridge by $580 \mathrm{~km}$. Darwin landed on the islets from the Beagle in 1832 and recognized that they are different from most oceanic islands in so far as they are not volcanic [Darwin, 1839]; in fact, they are made mostly of mylonitized mantlederived lherzolite [Melson et al., 1972; Bonatti, 1990] (supporting information Figure S1). There are five larger islets covering about $15,000 \mathrm{~m}^{2}$ (Figure 7); the maximum height above sea level reached by the islets is about $18 \mathrm{~m}$. The islets are at the summit of an East-West transverse ridge extending for $\sim 90 \mathrm{~km}$ adjacent the active St. Paul transform domain (St. Peter and St. Paul's Massif, according to Hekinian et al. [2000, Figure 7]). Transcurrent and transpressive seismic epicenters [Wolfe et al., 1993] and high-resolution bathymetry indicate that the Massif is affected by a left overstep along the right-lateral fault that causes transpressive uplift (Figure 7).

[37] Two erosional terraces are present in the three largest islets, 4-5 and 7-9 $\mathrm{m}$ above sea level 


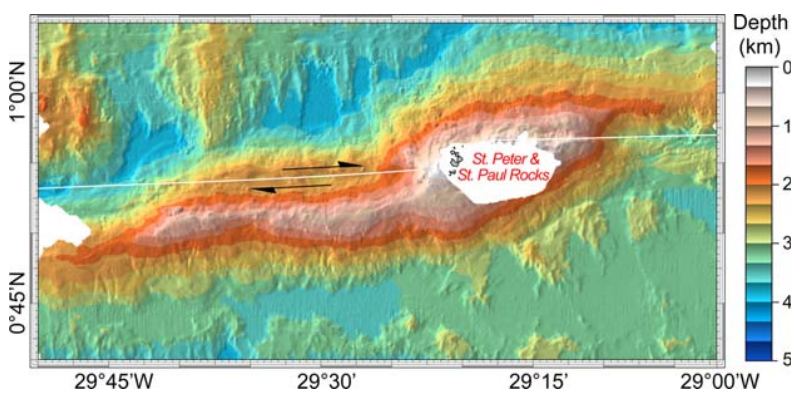

Figure 7. Bathymetry of the St. Peter and St. Paul's Massif (data from Gasperini et al. [1997a] and Hekinian et al. [2000]). The left overstep of the right-lateral St. Paul transform fault implies transpression at St. Peter and St. Paul Rocks area.

[Motoki et al., 2009], suggesting similar rates of uplift and absence of tilting in the islets. Based on ${ }^{14} \mathrm{C}$ age determinations on fossil sea level markers, the islets were subjected to uplift during the last 6600 years at an average rate of $\sim 1.5 \mathrm{~mm} / \mathrm{a}$ [Motoki et al., 2009; Campos et al., 2010]. St. Peter and St. Paul, then, are transform-related tectonic islands "in the making," with uplift that may possibly be followed by future subsidence, erosion, and formation of a carbonate platform.

\section{Discussion}

\subsection{Environmental Significance of the Vema and Romanche Carbonate Facies}

[38] The Vema and Romanche platforms show carbonate facies typically consisting of "rhodalgal associations" dominated by red algae and perforate large benthic foraminifera. Although corals were abundant during the Miocene, coral communities are present only as locally minor patch reefs, in contrast with many well-known examples from warm-water carbonate systems [Lees and Buller, 1972]. Factors influencing the biota communities include temperature and water fertility [Lees and Buller, 1972; Pomar, 2001; Brandano and Corda, 2002; Mutti and Hallock, 2003; Brandano et al., 2010]. Optimal temperature range for coral reef development is between 23 and $25^{\circ} \mathrm{C}$ [Veron, 1995]. Concerning nutrients, Larson et al. [1995] as well as Wilson et al. [1998] report a latitudinal crisis belt coinciding with the high productivity_upwelling equatorial belt. Tropical "nonchlorozoan" deposits similar to our carbonate facies are reported by Wilson and Vecsei [2005] in modern and Cenozoic platforms from SE Asia and northern Australia, inferring preferential develop- ment of these facies in humid tropical or nutrient upwelling areas. Based on latitude of the Vema and Romanche carbonate platforms, high seawater fertility rather than temperature was probably a major controlling factor. Equatorial upwelling and humid conditions may have increased shallow water absorption of light, favoring plankton blooms (note the abundance of planktonic foraminifera as nuclei of ooids and/or planktonic foraminifera with incipient coatings). This created conditions suitable for carbonate platforms dominated by nonframework building biota, such as larger benthic foraminifera and coralline algae, with only minor patch reefs containing Porites.

[39] The occurrence of Amphistegina in the limestones of Romanche Paleoisland C (Table 1) may suggest that these equatorial platforms could have served in the Miocene as stepping stones for the Caribbean-type Amphistegina assemblages that extend across the Atlantic to the Cabo Verde Islands [Bernoulli et al., 2007].

[40] The absence of reef facies on the Vema platform, in contrast to its presence, although minor, at the Romanche platforms, could be due to differences in water quality, related to run-off from adjacent land areas. Humid equatorial regions produce high terrestrial runoff and onshore organic productivity. As shown by Miocene equatorial carbonates from Indonesia [Wilson, 2002], some organisms are tolerant of high nutrient input (i.e., larger benthic foraminifera, pectinids, coralline algae, and echinoids) while corals (i.e., hermatypic corals) appear to be less tolerant. The latitude of the Vema transverse ridge $\left(11^{\circ} \mathrm{N}\right)$ is close to that of Caribbean reefs off northern Venezuela. Reef building suffered in this region (Falcón Basin) a decline in Early Miocene time attributed to changes in regional water quality [Edinger and Risk, 1994; Von der Heydt and Dijkstra, 2005]. Johnson et al. [1990] suggest that a switch in the outlet position of an ancestral Orinoco River might have caused the regional decline in reef building by altering surface-water characteristics just as modern Orinoco and Amazon outflows exert strong control on shallow-water habitats off the coast of northeastern South America. Observations from space, $\mathrm{Hu}$ et al. [2004] demonstrated the influx of continent-derived materials on open ocean waters over distances exceeding $2000 \mathrm{~km}$. Considering spreading rates, the Vema carbonate platform was closer to the continent during MidMiocene, suggesting that the Orinoco River terrigenous input influenced the carbonate producing biota, inhibiting the growth of coral communities. 


\subsection{Origin of Oceanic Tectonic Islands}

[41] The nonvolcanic islands described in this paper formed due to vertical motions of lithospheric blocks related to transform tectonics. Even slight changes in ridge/transform geometry, i.e., changes in orientation of mid-ocean ridge segments offset by transform boundaries, can cause either transtension or transpression along the transform resulting in vertical motions of lithospheric slabs [Bonatti, 1978]. Modern tectonic islands St. Peter-Paul Rocks, are still in a phase of uplift, representing the youthful stage in the "uplift-emersion-erosionsubsidence-carbonate platform formation" cycle typical of tectonic islands.

[42] Vertical motions are particularly well constrained at the Vema transform [Bonatti et al., 2005]. Ridge-parallel seafloor fabric immediately south of the Vema transform changed orientation by $\sim 5^{\circ}$ in $\sim 11-10$ Ma crust, implying a slight change in ridge/transform geometry that caused transtension normal to the transform. Flexure of the lithospheric slab bordering the southern side of the transform followed, with uplift of the edge of the slab along the transform boundary. Modeling suggests that uplift was maximal where lithospheric thickness was highest [Bonatti et al., 2005], that is, in the oldest western part of the slab that emerged above sea level. Uplift ceased after the ridge-transform system settled into the new geometry. Subsidence, subaerial erosion and truncation of the emerged slab at a sea level and growth of a shallow-water carbonate cap followed. The 11-10 Ma Sr isotopic ages of the carbonate platform are compatible with the timing of the flexure and uplift of the lithosphere slab estimated from magnetic anomalies. However, the presence in some of the platform samples of early Miocene fossils [Bonatti et al., 1994a] may indicate a first stage of crustal uplift at the inside corner high, followed by the transtensional uplift at 11-10 Ma. The average subsidence rate of the Vema transverse ridge has been estimated assuming that it subsided as a single block starting soon after the end of the uplift phase at $10 \mathrm{Ma}$. The spreading half rate decreased from $17.2 \mathrm{~mm} / \mathrm{a}$ between 26 and $19 \mathrm{Ma}$ to $\sim 16.9 \mathrm{~mm} / \mathrm{a}$ between 19 and $\sim 10$ $\mathrm{Ma}$, and then to $\sim 13.6 \mathrm{~mm} / \mathrm{a}$ from $10 \mathrm{Ma}$ to present [Bonatti et al., 2003], implying a 26-23 Ma crustal age below the carbonate cap. The wavetruncated horizontal surface of oceanic crust at the base of the carbonate platform lies presently 1100 $\mathrm{m}$ below sea level, suggesting an average subsidence rate slightly over $0.1 \mathrm{~mm} / \mathrm{a}$. This rate is higher than thermal subsidence $(<0.1 \mathrm{~mm} / \mathrm{a})$ of
26-23 Ma old crust predicted by the depth/square root of age law.

[43] The three Romanche sunken islands also formed due to transform-related transtension/ transpression, although processes and timing are less precisely constrained than at Vema. Given that erosional surfaces $R_{1}, R_{2}$, and $R_{3}$ lie at about the same depth below sea level, platforms A, B, and $\mathrm{C}$ formed probably during the same time interval. Combining sea level changes, stratigraphic determination on key fossil species, and the growth potential of bioconstructors through a numerical model, an age range between 23 and 17 Ma was obtained for platform A [Gasperini et al., 1997a]. This suggests a $0.06 \mathrm{~mm} / \mathrm{a}$ subsidence rate of the Romanche sunken islands since middle Miocene, assuming a present day $1200-1300 \mathrm{~m}$ depth of the erosional surface at the base of the carbonate platform. Sr isotopic ages of Romanche platform A samples (up to $10 \mathrm{Ma}$ ) are significant lower than those estimated by Gasperini et al. [1997b]. The complex tectonic framework of the eastern Romanche may have resulted in multiple stages of transtension/transpression and in more than one event of uplift, emersion and subsidence.

[44] Atlantis Bank originated as an oceanic core complex emplaced at the eastern ridge-transform intersection of the Atlantis II Fracture Zone on the Southwest Indian Ridge, that subsequently underwent additional uplift due to transtension across the transform due to a spreading direction change. Our data show that the carbonate rocks include a fauna deposited at around 100-200 m water depth around $4.5-2.4 \mathrm{Ma}$. It is presently $\sim 700 \mathrm{~m}$ deep, giving a subsidence rate of $0.1-0.2 \mathrm{~mm} / \mathrm{a}$. Assuming a constant subsidence rate, the bank was at sea level at around 7-5 Ma, earlier if the subsidence was faster. The exposed gabbros on the wave-cut platform are deeply pitted where chemical erosion removed plagioclase. Thus, layering and other features defined by less easily weathered pyroxene and amphibole stand out in videos and still camera images (supporting information Figure S2). This form of weathering is generally associated with a subaerial environment. Pitted samples and outcrops were collected by the Shinkai 6500 submersible down to below $1700 \mathrm{~m}$ water depth. Thus, given the subsidence rate inferred from our dating, Atlantis Bank was probably uplifted to $\sim 1000 \mathrm{~m}$ above sea level at or near the inside corner high. Similar modern uplifts are not known at ridgetransform intersections. However, Anna de Koningh Seamount is an ultramafic/gabbro tectonic block [Fisher et al., 1986] uplifted to 

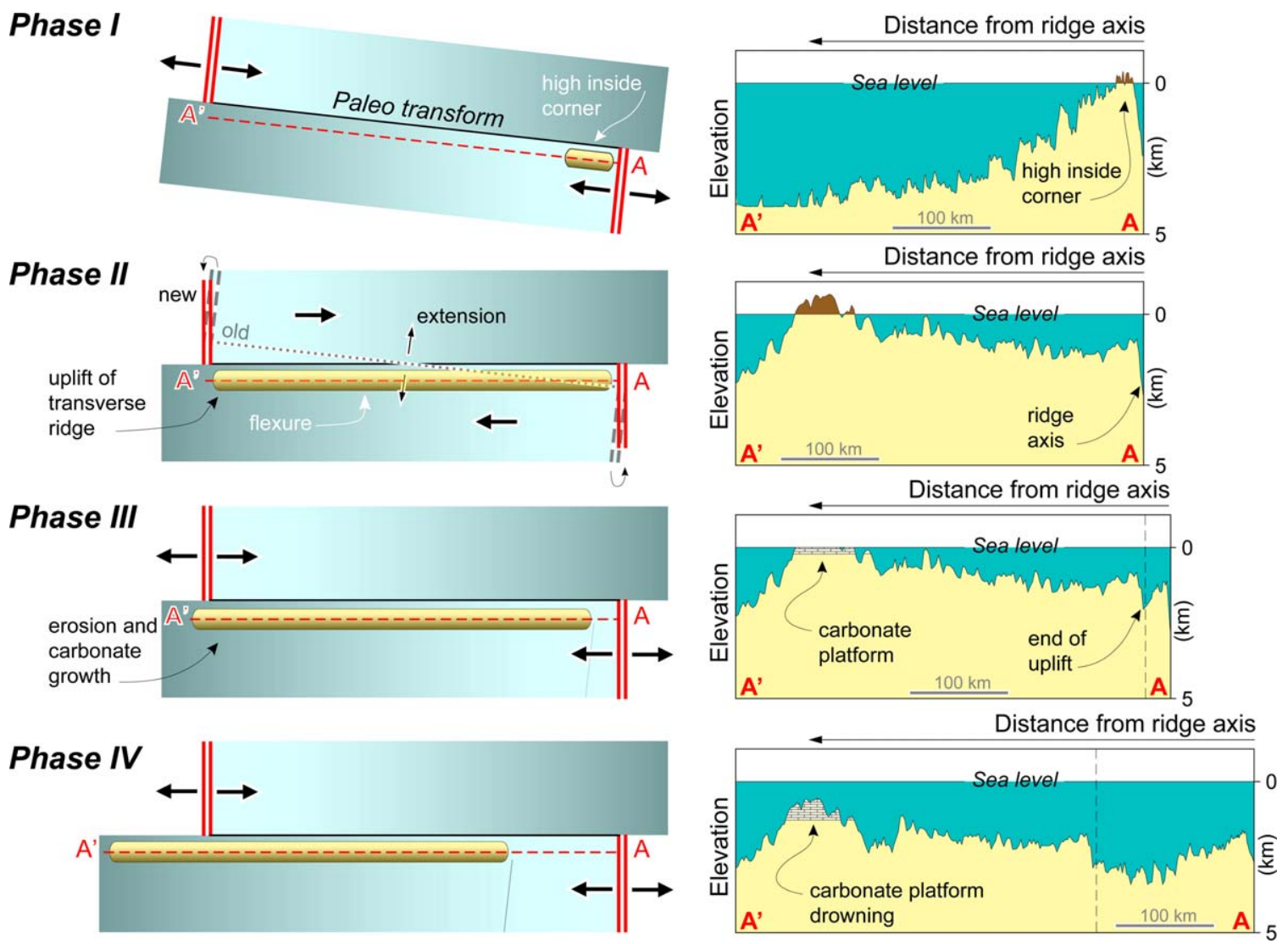

Figure 8. Cartoon showing the formation and evolution of tectonic islands. (left) Red dashed line A-A' marks the location of (right) the topographic profile. Phase I: Formation of a prominent inside-corner high at a long-offset ridge-transform intersection. Inside-corner high may reach sea level. Phase II: Change in plate kinematics causing local transtensional/transpressional tectonics resulting in uplift of a sliver of oceanic lithosphere and formation of the transverse ridge [Bonatti et al., 1994b; Pockalny et al., 1996; Bonatti et al., 2005]. Phase III: End of uplift and erosion of the emerged portions of the transverse ridge at or close to sea level with the formation of wave-cut terraces. Thermal subsidence starts allowing space for carbonate platform growth. Phase IV: Carbonate platform drowning due to environmental stress-induced deterioration in the potential for platform growth and/or tectonic-controlled rapid-sinking of the transverse ridge.

$\sim-234 \mathrm{~m}$ at the western inside-corner high of the DuToit F.Z. on the Southwest Indian Ridge, suggesting that large uplifts can occur in such settings.

\subsection{Oceanic Islands : A Classification}

[45] Oceanic islands (excluding continental fragments) can be classified in two main groups: (a) "hot" volcanic islands and (b) "cold" tectonic islands. The "hot" volcanic islands include two subgroups: $\left(\mathrm{a}_{1}\right)$ islands formed by excess volcanism due to mantle melting anomalies either along mid-ocean ridges or within oceanic plates; $\left(a_{2}\right)$ islands formed by excess volcanism due to suprasubduction "wet" mantle melting, i.e., island arcs. "Cold" tectonic islands include those due to transform-related vertical tectonic movements of slivers of oceanic lithosphere, as described in this paper (Figure 8). Tectonic islands are preferentially found along transverse ridges and insidecorner highs flanking transform faults at slow and ultraslow spreading ridges, where large vertical motions are common (Figure 8).

[46] "Hot" islands rise above sea level, evolve, and sink within time intervals that depend mostly on the velocity of the oceanic plate relative to the source of the mantle melting anomaly. The lifetimes of volcanic islands from fast-spreading oceans (i.e., the Hawaiian Chain) tend to be shorter than those from slow-spreading oceans (i.e., Canaries, Cabo Verde). Hot islands are generally constructed of erupted basaltic rocks, including low-density pyroclastics and hyaloclastites. Tectonic islands, however, are made of 
uplifted tectonic massifs of lower ocean crust and mantle gabbro and peridotite, unroofed along detachment faults at ridge/transform intersections and/or uplifted due to changes in ridge/transform geometry causing transtension and/or transpression. Although they generally have an anomalously high bulk density compared to the surrounding crust, they are often anomalously uplifted relative to the age-depth subsidence curve.

[47] Carbonate platforms can develop on oceanic islands, given favorable biological, physical, and chemical conditions. The geometry of carbonate platforms depends on: pre-existing topography (either a volcanic system or an uplifted lithospheric block), as well as on hydraulic energy and type of produced sediment that, in turn, is controlled by environmental conditions. The morphology of the platforms tends to be different in the two classes of islands. Volcanic islands tend to form circular or subcircular platforms, that can enclose areas of low-energy (lagoons), in a scheme hinted at already by Darwin [1842]. In contrast, tectonic islands, generally associated with transform offsets, form long and narrow platforms, elongated parallel to the transform (Figure 8). An example is the $\sim 50 \mathrm{~km}$ long, $\sim 3 \mathrm{~km}$ wide Vema Paleoisland (Figures 2a and 3a). Low-energy lagoons are rare in tectonic islands, due to their long-narrow basement morphology.

[48] Rate of production and accumulation of carbonate sediments is affected by rate of vertical motion and eustatic sea level oscillations, that is, the rate at which accommodation space is created. During sea-level rise, platforms on volcanic islands can aggrade in all depositional systems (from the lagoon to the margin) enhancing carbonate production, and can aggrade and prograde during sea-level fall and still stand (low or highstand). In contrast, carbonate platforms on tectonic island can aggrade during sea-level rise but their peculiar long and narrow morphology can affect the efficiency of the carbonate factory and thus the amount of carbonate production. During sea-level fall and still stand, being the escarpments generally very steep, little progradation can occur and significant volumes of produced material may be shed off the platform edge into the transform valley.

[49] In conclusion, the evolution of tectonic sunken islands in the Atlantic and in the Indian Oceans has been reconstructed based on seismic reflection data, facies analysis, and carbonate $\mathrm{Sr}$ - isotopic dating. St. Peter-Paul Rocks (equatorial Atlantic) are a modern example of a tectonic island "in the making." "Cold" tectonic islands from different oceans and spreading rates display similar histories of uplift and subsidence, driven by the combined effects of vertical tectonics and lithospheric cooling, different from those of typical "hot" volcanic islands characterized by rapid growth and subsequent monotonic subsidence.

\section{Acknowledgments}

[50] Work supported by the Italian Consiglio Nazionale Ricerche and Fondazione Onlus Rita Levi-Montalcini. Thanks are due to G. Bortoluzzi (Ismar-CNR) for helping out with the open source software GMT ("General Mapping Tools"). Thanks are also given to C.J. MacLeod and P.T. Robinson cochief scientists with HJBD of James Clark Ross Cruise 31 to Atlantis Bank for making available samples and data. We are grateful to L. Di Bella for Atlantis Bank planktonic foraminifera analysis and to D. Bernoulli and an anonymous reviewer for constructive comments that helped us to improve the paper. This is LSCE contribution n. 5113.

\section{References}

Abreu, V. S., and J. B. Anderson (1998), Glacial eustasy during the Cenozoic: Sequence stratigraphic implications, Bull. Am. Assoc. Petrol. Geol., 82, 1385-1400.

Baines, G., M. J. Cheadle, H. J. B. Dick, A. Hosford Scheirer, B. John, N. Kusznir, and T. Matsumoto (2003), Mechanism for generating the anomalous uplift of oceanic core complexes: Atlantis Bank, southwest Indian Ridge, Geology, 31, 1105-1108.

Bernoulli, D., L. Hottinger, S. Spezzaferri, and P. Stille (2007), Miocene shallow-water limestones from Sao Nicolau (Cabo Verde): Caribbean-type benthic fauna and time constraints for volcanism, Swiss J. Geosci., 100, 215-255.

Bolli, H. M., and J. B. Saunders (1989), Oligocene to Holocene low latitude planktic foraminifera, in Plankton Stratigraphy, Cambridge Earth Sci. Ser., vol. 1, edited by H. M. Bolli, J. B. Saunders, and K. Perch-Nielsen, pp. 155-262, Cambridge Univ. Press, Cambridge, U. K.

Bonatti, E. (1978), Vertical tectonism in oceanic fracture zones, Earth Planet. Sci. Lett., 37, 369-379.

Bonatti, E. (1990), Subcontinental mantle exposed in the Atlantic Ocean on St. Peter-Paul islets, Nature, 345, 800-802.

Bonatti, E., M. Sarnthein, A. Boersma, M. Gorini, and J. Honnorez (1977), Neogene crustal emersion and subsidence of the Romanche Fracture Zone, equatorial Atlantic, Earth Planet. Sci. Lett., 35, 369-383.

Bonatti, E., R. Sartori, and A. Boersma (1983), Vertical crustal movements at the Vema Fracture Zone in the Atlantic: Evidence from dredged limestones, Tectonophysics, 91, 213216.

Bonatti, E., M. Ligi, L. Gasperini, G. Carrara, and E. Vera (1994a), Imaging crustal uplift, emersion and subsidence at the Vema Fracture Zone, Eos Trans. AGU, 75, 371.

Bonatti, E., M. Ligi, L. Gasperini, A. Peyve, Y. Raznitsin, and Y. J. Chen (1994b), Transform migration and vertical 
tectonics at the Romanche fracture zone, equatorial Atlantic, J. Geophys. Res., 99, 21,779-21,802.

Bonatti, E., M. Ligi, A. M. Borsetti, L. Gasperini, A. Negri, and R. Sartori (1996), Lower Cretaceous deposits trapped near the Mid-Atlantic Ridge, Nature, 380, 518-520.

Bonatti, E., M. Ligi, D. Brunelli, A. Cipriani, P. Fabretti, V. Ferrante, L. Gasperini, and L. Ottolini (2003), Mantle thermal pulses below the Mid-Atlantic Ridge and temporal variations in the formation of oceanic lithosphere, Nature, 423, 499-505.

Bonatti, E., D. Brunelli, W. R. Buck, A. Cipriani, P. Fabretti, V. Ferrante, L. Gasperini, and M. Ligi (2005), Flexural uplift of a lithospheric slab near the Vema transform (central Atlantic): Timing and mechanisms, Earth Planet. Sci. Lett., 240, 642-655.

Brandano, M., and L. Corda (2002), Nutrients, sea level and tectonics: Constrains for the facies architecture of Miocene carbonate ramp in central Italy, Terra Nova, 14, 257-262.

Brandano M., M. Brilli, L. Corda, and M. Lustrino (2010), Miocene $\mathrm{C}$-isotope signature from the central Apennine successions (Italy): Monterey versus regional controlling factors, Terra Nova, 22, 125-130.

Campos, T. F. C., F. H. R. Bezerra, N. K. Srivastava, M. M. Vieira, and C. Vita-Finzi (2010), Holocene tectonic uplift of the St Peter and St Paul Rocks (equatorial Atlantic) consistent with emplacement by extrusion, Mar. Geol., 271, 177186.

Cande, S. C., J. L. LaBraque, and W. F. Haxby (1988), Plate kinematics of the South Atlantic: Isochron C34 to present, $J$. Geophys. Res., 93, 13,479-13,492.

Cerveny, V., L. Klimes, and I. Psencik (1988), Application of dynamic ray tracing, Phys. Earth Planet. Inter., 51, 25-35.

Coffey, B. P., and J. F. Read (2007), Subtropical to temperate facies from a transition zone, mixed carbonate-siliciclastic system, Palaeogene, North Carolina, USA, Sedimentology, 54,339-365.

Corda, L., and M. Brandano (2003), Aphotic zone carbonate production on a Miocene ramp, central Apennines, Italy, Sediment. Geol., 161, 55-70.

Darwin, C. R. (1839), Journal of Researches into the Geology and Natural History of the Various Countries Visited by H.M.S. Beagle under the Command of Captain Fitzroy, R. N. From 1832 to 1836, Henry Colburn, London.

Darwin, C. R. (1842), Coral Reefs, Smith-Elder, London.

Darwin, C. R. (1844), Geological Observations on the Volcanic Islands Visited During the Voyage of H.M.S. Beagle, Together with Some Brief Notices of the Geology of Australia and the Cape of Good Hope. Being the Second Part of the Geology of the Voyage of the Beagle, Under the Command of Capt. Fitzroy, R.N. During the Years 1832 to 1836, Smith-Elder, London.

Dick, H. J. B., C. J. MacLeod, P. T. Robinson, S. Allerton, and M. Tivey (1999), A high resolution bathymetric map of Atlantis Bank, in Proceedings of Ocean Drilling Program, Initial Reports, vol. 176, edited by H. J. B. Dick et al., Back envelope map, U.S. Gov. Print. Off., Washington, D. C.

Dick, H. J. B., et al. (2000), A long in-situ section of the lower Ocean Crust: Results of ODP Leg 176 drilling at the Southwest Indian Ridge, Earth Planet. Sci. Lett., 179, 31-51.

Edinger, E. N., and M. Risk (1994), Oligocene-Miocene extinction and geographic restriction of Caribbean Corals: Roles of turbidity, temperature and nutrients, Palaios, 9, 576-598.
Edmond, J. M. (1992), Himalayan tectonic, weathering processes, and the strontium isotope record in marine limestones, Science, 258, 1594-1597.

Fabretti, P., et al. (1998), First results of cruise S19 (PRIMAR Project); petrological and structural investigations of the Vema transverse ridge (equatorial Atlantic), Giornale di Geologia, 60, 3-16.

Fisher, R. L., H. J. B. Dick, J. Natland, and P. S. Meyer (1986), Mafic/ultramafic suites of the slowly spreading Southwest Indian Ridge: PROTEA Exploration of the Antarctic Plate Boundary, $24^{\circ} \mathrm{E}-47^{\circ} \mathrm{E}$, Ofioliti, $11,147-178$.

Fornos, J. J., and W. M. Ahr (1997), Temperate carbonates on a modern, low-energy, isolated ramp: The Balearic platforms, Spain, J. Sediment. Res., 67, 364-373.

Gasperini, L., et al. (1997a), New data on the geology of the Romanche F.Z., equatorial Atlantic: PRIMAR-96 cruise report, Giornale di Geologia, 59, 3-18.

Gasperini, L., E. Bonatti, M. Ligi, R. Sartori, A. Borsetti, A. Negri, A. Ferrari, and S. Sololov, (1997b), Stratigraphic numerical modeling of a carbonate platform on the Romanche transverse ridge, equatorial Atlantic, Mar. Geol., 136, 245257.

Gasperini, L., D. Bernoulli, E. Bonatti, M. Borsetti, M. Ligi, A. Negri, R. Sartori, and K. von Salis (2001), Lower Cretaceous to Eocene sedimentary transverse ridge at the Romanche Fracture Zone and the opening of the equatorial Atlantic, Mar. Geol., 176, 101-119.

Gebelein, C. D. (1974), Guidebook for Modern Bahamian Platform Environments: Field Trip: Geological Society of America, Annual Meeting, Bermuda Biol. Stn, University of California, Los Angeles.

Grigg, R. W. (1982), Darwin point: A threshold for atoll formation, Coral Reefs, 1, 29-34.

Halfar, J., and M. Mutti (2005), Global dominance of coralline red-algal facies: A response to Miocene oceanographic events, Geology, 33, 481-484.

Hallock, P., and W. Schlager (1986), Nutrient excess and the demise of coral reefs and carbonate platforms, Palaios, 1 , 389-298.

Haq, B. U., J. Hardenbol, and P. R. Vail (1987), Chronology of fluctuating sea-levels since the Triassic, Science, 235, 11561167.

Hekinian, R., T. Juteau, E. Gràcia, B. Sichler, S. Sichel, G. Udintsev, R. Apprioual, and M. Ligi (2000), Submersible observations of equatorial Atlantic mantle: The St. Paul Fracture Zone region, Mar. Geophys. Res., 21, 529-560.

Hu C., E. T. Montgomery, R. W. Schmitt, and F. E. MullerKarger (2004), The dispersal of the Amazon and Orinoco River water in the tropical Atlantic and Caribbean Sea: Observation from space and S-PALACE floats, Deep Sea Res., Part II, 51, 1151-1171.

Iaccarino, S. M., I. Premoli Silva, M. Biolzi, L. M. Foresi, F. Lirer, E. Turco, and M. R. Petrizzo (2007), Practical Manual of Neogene Planktonic Foraminifera, Int. Sch. on Planktonic Foraminifera, Tipografia Pontefelcino, Perugia, Italy.

James, N. P. (1997), The cool-water carbonate depositional realm, in Cool-Water Carbonates, SEPM Special Publication, vol. 56, edited by N. P. James and J. Clarke, pp. 1-20, Tulsa, Okla.

James, N. P., Y. Bone, C. Von Der Borch, and V. A. Gostin (1992), Modern carbonate and terrigenous clastic sediments on a cool water high energy, mid-latitude shelf: Lapacede, southern Australia, Sedimentology, 39, 877-903.

James, N. P., L. S. Collins, Y. Bone, and P. Hallock (1999), Subtropical carbonates in a temperate realm: Modern 
sediments on the southwest Australian Shelf, J. Sediment. Res., 69, 1297-321.

Johnson, K. G., M. Sanchez-Villagra, and O. A. Aguilera (1990), The Oligocene-Miocene transition on the coral reefs in the Falcòn Basin (NW Venezuela), Palaios, 24, 59-69.

Larson, R. L., E. Erba, M. Nakanishi, D. D. Bergersen, and J. M. Lincoln (1995), Stratigraphic vertical subsidence and paleolatitudinal histories of Leg 144 Guyot, Proc. Ocean Drill. Program Sci. Results, 144, 915-933.

Lees, A. (1975), Possible influence of salinity and temperature on modern shelf carbonate sedimentation, Mar. Geol., 19, 159-198.

Lees, A., and A. T. Buller (1972), Modern temperate-water and warm-water shelf carbonate sediments contrasted, Mar. Geol., 13, M67-M73.

Li, D., G. A. Shields-Zhou, H. F. Ling, and M. Thirlwall (2011), Dissolution methods for strontium isotope stratigraphy: Guidelines for the use of bulk carbonate and phosphorite rocks, Chem. Geol., 290, 133-144.

Ligi, M., and G. Bortoluzzi (1989), PLOTMAP: Geophysical and geological applications of good standard quality cartographic software, Comput. Geosci., 15, 519-585.

Ligi, M., E. Bonatti, L. Gasperini, and A. N. B. Poliakov (2002), Oceanic broad multifault transform plate boundaries, Geology, 30, 11-14.

McArthur, J. M., and R. J. Howarth (2004), Sr-isotope stratigraphy, in A Geological Timescale 2004, edited by F. Gradstein, J. Og, and A. G. Smith, pp. 96-105, Cambridge Univ. Press, Cambridge, U. K.

McArthur, J. M., R. J. Howarth, and T. R. Bailey (2001), Strontium isotope stratigraphy: LOWESS version 3. Best-fit line to the marine Sr-isotope curve for 0 to $509 \mathrm{Ma}$ and accompanying look-up table for determining numerical ages, J. Geol., 109, 155-169.

Melson, W. J., S. R. Hart, and G. Thompson (1972), St. Paul's rocks, equatorial Atlantic: Petrogenesis, radiometric ages, and implications on sea-floor spreading, Geol. Soc. Am. Mem., 132, 241-272.

Morgan, W. J. (1972), Deep mantle convection plumes and plate motions, $A A P G$ Bull., 56, 203-213.

Motoki, A., S. E. Sichel, T. F. C. Campos, N. K. Srivatav, and R. Soares (2009), Taxa de soerguimento atual do arquipélago de Sao Pedro e Sao Paulo, Oceano Atlantico Equatorial, Rem: Rev. Esc. Minas, 62, 331-342.

Mutti, M., and P. Hallock (2003), Carbonate systems along nutrients and temperature gradients: Some sedimentological and geochemical constraints, Int. J. Earth Sci., 92, 465-475.

Mutti, M., D. Bernoulli, and P. Stille (1997), Temperate carbonate platform drowning linked to Miocene oceanographic events: Maiella platforms margin, Italy, Terra Nova, 9, 122125 .

Natland, J. H., and H. J. B. Dick (2001), Formation of the lower ocean crust and the crystallization of gabbroic cumulates at a very slowly spreading ridge, J. Volcanol. Geotherm. Res., 110, 191-233.

Nebelsik, J. H. (1989), Temperate water carbonate facies of early Myocene Paratethys (Zogelsdorf Formation, lower Austria), Facies, 21, 11-40.

Nelson, C. S., S. L. Keane, and P. S. Head (1988), Non-tropical carbonate deposits on the modern New Zealand shelf, Sediment. Geol., 60, 71-94.

Pockalny, R. A., P. Gente, and W. R. Buck (1996), Oceanic transverse ridges: A flexural response to fracture-zonenormal extension, Geology, 24, 71-74.

Pomar, L. (2001), Types of carbonate platforms: A genetic approach, Basin Res., 13, 313-334.

Sclater, J. G., R. N. Anderson, and M. Lee Bell (1971), Elevation of ridges and evolution of the central eastern Pacific, $J$. Geophys. Res., 76, 7888-7915.

Terakado, Y., H. Shimizu, and A. Masuda (1988), Nd and Sr isotopic variations in acidic rocks formed under a peculiar tectonic environment in Miocene Southwest Japan, Contrib. Mineral. Petrol., 99, 1-10.

Veron, J. E. N. (1995), Corals in Space and Time. The Biogeography and Evolution of the Scleractinia, Cornell Univ. Press, Ithaca, New York.

Von der Heydt, A., and H. A. Dijkstra (2005), Flow reorganization in the Panama Seaway: A cause for the demise of Miocene corals? Geophys. Res. Lett., 32, L02609, doi:10.1029/2004GL020990.

Wessel, P., and W. H. F. Smith (1998), New improved version of the Generic Mapping Tools released, Eos Trans. AGU, $79,579$.

Wilson, J. T. (1963), A possible origin of the Hawaiian Islands, Can. J. Phys., 41, 863-870.

Wilson, M. E. J. (2002), Cenozoic carbonates in Southeast Asia: Implication for equatorial carbonate development, Sediment. Geol., 147, 295-428.

Wilson, M. E. J., and A. Vecsei (2005), The apparent paradox of abundant foramol facies in low latitudes: Their environmental significance and effect on platform development, Earth Sci. Rev., 69, 133-168.

Wilson, P. A., H. C. Jenkyns, H. Elderfield, and R. L. Larson (1998), The paradox of drowned carbonate platforms and the origin of Cretaceous Pacific guyots, Nature, 30, 889-894.

Wolfe, C. J., E. A. Bergman, and S. C. Solomon (1993), Oceanic transform earthquakes with unusual mechanisms or locations relation to fault geometry and state of stress in the adjacent lithosphere, J. Geophys. Res., 98, 16,187-16,211. 